\title{
PUBLICATIONS
} DE LA

SOCIÉTÉ POUR L'ÉTUDE ET LA PROTECTION DES MAMMIFERES

\section{FORAMEN OVALE AND DUCTUS ARTERIOSUS BOTALLI IN AQUATIC NAMMALS}

by

\author{
E. J. SLIJPER
}

Netheriands Whale Research Group T.N.O., Zoological Laboratory, University of Amsterdam

Recherches sur l'occlusion du trou ovale et sur le canal artériel de Botal chez les mammifères aquatiques, reposant sur de nombreuses dissections de Baleinoptères, Marsouins, Phoque veau-marin et divers autres Pinnipèdes. Le trou ovale s'oblitère peu de temps après la naissance, sauf chez le phoque veatumarin oú ce phénomène est retardé. Le canal artériel de Botal s'oblitère à un âge de $2-5$ semaines chez les Pinnipèdes (sauf le phoque veau-marin), 4-14 mois chez le Marsouin ef les autres Delphinidés, et reste ouvert aumoins jusqu’à 13 ans chez les Baleinoptères. Cette oblitération est done considérabiement retardée par rapport anx animaux terrestres. Ces faits sont en rapport avec la tension en oxygène du sang. L'élévation de celle-ci après la naissance entrâne l'occlusion du canal; une déficience en oxygène est au contraire capable de l'ouvrir à nouveau. L'auteur examine la biologie des animaux marins en fonction de ces diverses données et compare notamment les Cétacés ế le Phoque veau-marin aux autres Pinnipèdes, dont les jeunes ne pénètrent dans l'eau qửấgés de $3-4$ semaines au moins et parfois plus.

\section{1. - INTRODUCTION}

In the early part of the 17 th century, William Harvey published his theory about the function of the ductus arteriosus, that had already been described by Galen and had been rediscovered by the French physician Botallo. Harvey studied the function of the ductus in connection with that of the foramen ovale and found that both embryonic pathways close at birth or at least soon after birth. In the early part of the 19 th century several authors pointed to the fact that in this respect the aquatic mammals differ from their terrestrial relatives. On the 20th of March 1822 the well known Dutch anatomist W. Vrolik got his doctors degree on a thesis dealing with the anatomy of the Common Seal (Phoca vitulina L.). One of the specimens he had dissected, had an open foramen ovale 
but - as opposed to Buffon-Daubenton (1799) who ascribed the ability of diving to the open foramen ovale - Vrolik ascribed this ability to the hepatic venous sinuses. He declared that the open foramen was an abnormality. Cuvier $(1805,1936)$ held that in Cetacea the ductus Botalli remained open throughout the entire life and the same opinion can be found in the work of Mackay (1886), van Gelderen (1928), Gray (1934), Ommanney (1935, especially large whales) and Thle c. s. (1948). Meckel (1831), Rapp (1837) and Marschner (1901), on the contrary, held that in whales, dolphins and seals the closure of the ductus is retarder. Among the aquatic mammals it would close earlier in animals that periodically go on land (Pinnipeds), than in those who are exclusively agruatic (Cetacea). According to the opinion of these authors the pressure in the pulmonary artery would be raised during diving, and the blood would be pressed throngh the ductus arteriosus into the aorta. Slijper (1936) collected a great number of data and drew the conclusion that in Cetaceans the foramen ovale closes shortly after birth. The histological closure of the ductus arteriosus, however, appeared to be retarded, although the cause of this retardation remained still unknown. The opinion of Pohlmann (1909, 1924) and Kellogg (1928), that no blood would pass through the ductus when the foramen is closed, has been proved to be incorrect.

However, the above-mentioned conclusions were based on very incomplete data. There was practically no information about Baleen. Whales and about Pinnipeds other than the Common Seal, and in a great number of data from Toothed Whales and Common Seals the age of the animals was not known. Since our knowledge of the causes of closure of the ductus arteriosus in terrestrial mammals has increased very much during the last 25 years, it is expedient to reconsider the question of the embryonic pathways in aquatic mammals on the basis of more extensive materials. Thanks to the support of the Netherlands Whaling Company I got the opportunity to disseet 22 hearts of Blue and Fin Whales (Balaeroptera musculus (L.), Balaenoptera physalus (L.)) on board of the floating factory "Willem Barendsz 》 in the Antarctic whaling, season 1946-1947. Grateful acknowledgement is also made to Mss. A. C. V. van Bemmel (Blijdorp-Rotterdam), C. van Doorn (Blijdorp-Rotterdam), C. van Delft (Ijmuiden), W. H. Dudok van Heel (den Helder), G. J. de Haan (Texel), A. L. Kelly (La Jolla), V. B. Scheffer (Seattle), B. Rasmussen (Bergen-Norway), H. K. 
Hewer (London) and I. A. McLaren (Montreal), for providing material of Cetaceans and Pinnipeds. For assistance and information grateful acknowledgement is made to Mss. J. B. Ruud (Oslo), M. M. Sleptzov (Moscow), J. L. van Haaften (Arnhem), C. Naaktgeboren (Amsterdam) and Mr. and Mrs. van Utrecht (Amsterdam). Thanks to this collaboration the present researches could be based on data from 53 Common Porpoises, 22 Blue and Fin Whales, 39 other Cetaceans, 20 Common Seals and 37 other Pinnipeds.

$$
\text { II. - DATA }
$$

The data about the foramen ovale and ductus arteriosus Botalli in Cetacea and Pinnipedia are collected in tables 1-6. The date of eapture, length and weight of the animals, characteristics of the teeth, the stomach contents and the genital organs made it possible to determine whether the animals were newborn, suckling, sexually immature, sexually mature or old. In most cases it was also possible to make an estimate of the absolute age of the animals based on data collected by Havinga (1933; Common Seal), Mohr (1955 ; Common Seal), Harrison (1960; Common Seal), Möhl Hansen (1954; Common Porpoise) and Slijper (1958; Cetaceans ; data from different authors).

Recent investigations on terrestrial mammals have shown that a distinction should be made between the physiological and the anatomical closure of the ductus. Almost immediately after birth the musculature of the ductus contracts and closes the lumen. Under certain circumstances, however, the ductus may reopen so that blood can pass through. During the stage of physiological closure of the ductus it has always a distinguishable lumen in the dead animal because after death the muscle fibres relax. Histological alterations in the wall of the vessel cause a gradual narrowing of the lumen and ultimately cause its complete obliteration (see sub VIII). Then the ductus is anatomically elosed.

The data about foramen and ductus arteriosus collected in the tables bear upon anatomical closure. The ductus is called closed when at least in a part of this vessel the lumen is completely obliterated, although in other parts a small probe may still be inserted. If this probe can pass the entire ductus, the vessel is called open, even if it is obvious that no blood would have passed through if the animal would be still alive. 


\section{III. - Conclusions WITH REgard to aquatic MaMmals}

\section{Common Porpoise (Phocaena phocaena (L.))}

Table 1 shows that in this species during the first ten days after birth the foramen ovale is still open, or that at least there are still some apertures in the valve that closes the foramen. After the 10th day, however, the foramen generally is anatomically closed. Specimen Nr. 16 and a five months old animal described by Marschner (1901) may be regarded as abnormal.

During the first ten days after birth the ductus arteriosus of the dead animal shows a wide lumen. It is but little narrower than in the foetus just before birth. It may be supposed that in the living animal the musculature of the ductus is so much contracted that no blood can pass through, although it is quite possible that this musculature relaxes now and than so that blood may pass through the vessel in comparatively large quantities. One month after birth the diameter of the lumen is about $1,5 \mathrm{~mm}$. Probably in the living animal blood flows through from time to time, athough in smaller quantities than in the first ten days after birth. Then the Iumen narrows gradually and at $2-3$ months only a very small probe can pass it. It may be supposed that at this age no or practically no blood will pass the ductus in the living animal. Specimen NI. 16 may be regarded as an abnormality. The anatomical closure probably starts at an age of 4 months, i. e. : halfway the suckling period. The first completely closed ductus appears at an age of 5 months. The older the animals are, the greater is the percentage of anatomically closed ductus, and in practically all animals the vessel is completely closed at an age of 14 months, i. e. : the age of sexual maturity. From 24 sexually mature animals only 3 still had an open ductus Botalli. Specimen $\mathrm{Nr} .10$ must be left out of consideration because this animal of $121 \mathrm{~cm}$ and $26 \mathrm{~kg}$ was already physically mature which is quite abnormal. In animals whose age was estimated at 6 years or older, not a single open ductus was found.

The anatomical closure of the ductus begins at the side of the aorta, than the pulnonary side closes and finally the lumen in the middle of the ductus is obliterated. Sclerotic tissue was only found in two cases in the aortic wall at the entrance of the ligamentum Botalli. In this respect the Common Porpoise difers 
markedly from the big Baleen Whales where sclerotic tissue was often found in the pumonary wall.

In the umbilical artery obliteration of the lumen apparently begins immediately after birth. In all animals older than one month the artery has become a solid ligament, that in some specimens even may have disappeared. The umbilical vein remains open until the age of sexual maturity, although its lumen is comparatively narrower than before birth. It drains blood from the epigastric vein (Slijper, 1936). After sexual maturity, however, the Iumen of the vein shows a distinct tendency to obliterate.

\section{Blue and Fin Whales (Balaenoptera musculus (L.) and Balae- noptera physalus (L.)).}

On account of the length limit in the catch of Blue and Fin Whales it was impossible to dissect hearts of very young animals. The youngest animal had an estimated age of about $3 \frac{1}{3}$ years, the eldest was about 13 years old.

In these animals the duetus arteriosus had a length of $8-20 \mathrm{~cm}$ and a diameter of $4-7 \mathrm{~cm}$. Table 2 and 3 show that in all animals the ductus was either completely closed or that it had a very narrow lumen. In none of the cases blood was found in the Iumen, but in many cases there was a mass of necrotic tissue. This may signify that in the living animals no blood passed through the ductus. The tables show that the vessel may be anatomically closed before sexual maturity, but that it may also retain a narrow lumen through its entire length until the age of physical maturity (about 13 years). The percentage of open ductus in sexually mature animals is much larger than in the Common Porpoise. From these data it appears probable that the first stages of closure of the ductus pass off in the same way as in the Porpoise, but that the ultimate closure of the vessel is much more retarded than in this animal. The date on Baleen whales found in the literature (table 4 ) are quite in accordance with the above mentionad observations.

The elosure of the ductus begins at the pulmonary side. In almost every animal there is a deep pit in the pulmonary wall at the entrance of the ductus (ligamentum) Botalli. In the aortic wall the pit may be also present, but it is much shallower. In the pulmonary wall and also in the wall of the ductus (ligamentum 
itself (at the pulmonary side), there may be greater or smaller quantities of sclerotic tissue. In a number of cases this tissue is strongly calcified and it may be supposed that the selerotic tissue is an earlier stage of the calcified tissue. Sclerotic tissue and calcifrcation have been found in the pulmonary wall and in the wall of the ductus itself in animals with an open as well as in those with a closed ductus. With one exception (a small patch of sclerotic tissue) sclerotic and calcified tissue have never been found in the aortic wall or at the aortic side of the ductus Botalli. The coincidence of a deep pit and calcified and sclerotic tissue suggests that the appearance of these tissues may be ascribed to traction forces of the contracting ductus (ligament) exerted on the pulmonary wall.

All data about the foramen ovale (see also table 4) suggest that it closes shortly after birth.

\section{Other Celacea.}

Although the number of data is still very small, table 4 shows that the closure of the ductus arteriosus in Delphinidae occurs in the same way as in the Common Porpoise. The anatomical closure begins hale-way the suckling period and in practically all animals the ductus is completely closed at the age of sexual matrrity. Psendorca seems io be a little bit more retarded, but more extensive material may show that it sill fits into the scheme. It is very important to establish that in two sexually mature Sperm Whales (Physeter macrocephalus L.) the ductus arteriosus was still open and that in one of them there was even a fairly wide inmen. In this respect the process in the Sperm Whale difers from that in the other Toothed Whales. It is more or less the same as in the Baleen Whales, where the closure of the ductus is also much more retarded than in Delphinids. At the moment it is not yet possible to decide whether this phenomenon should be ascribed to the size of the animals (and consequently to the size of their ductus) or to their habit of deep diving. The Bottlenosed Whale (Hyperoodon ampullatus (Forster)), which is also a deep diver, probably shows the same type of retardation as the Sperm Whale, but the available material does not permit to draw definite conclusions.

In all Cetaceans the closure of the foramen ovale and the 
umbilical vessels appears to pass in exactly the same way as in the Common Porpoise.

\section{Common Seal (Phoca vitulina L.).}

The data of table 5 show that during the first eight weeks after birth - i. e. the period in which the young is suckled -, the ductus arteriosus Botalli is always entirely open. In the dead animal the lumen may even be fairly wide (up to $4 \mathrm{~mm}$ ). This suggests that in the living animal blood has passed through the ductus from time to time. The case described by Garrod (1877) is difficult to explain. The author mentions the presence of remnants of the umbilical cord, but the length of the animal $(90 \mathrm{~cm}$ ) and the date of capture (9th of October) suggest that the animal may have been older than was estimated by the author. At the age of 8 weeks the ductus begins to close. Between 8 and 13 weeks the passage may be found open as well as closed, but in animals over the age of 13 weeks the ductus is invariably closed. This is quite in accordance with the data from Rapp (1837), Meckel (1831; the same animals) and Marschner (1901). Consequently the closure of the ductus is retarded in the Common Seal, but not as much as in the Common Porpoise and in Delphinidae.

The ductus arteriosus of the Common Seal is long compared with that of Cetaceans and the majority of the terrestrial mammals. The closure probably begins at the aortic side. Sclerotic or calcified tissue has not been found.

As opposed to the Cetaceans the closure of the foramen ovale occurs in the same way as that of the ductus Botalli. It closes much later than in whales and dolphins and up to the age of 8 weeks it is still open. During this period an opening of $12 \mathrm{~mm}$ diameter may still be present. Closure takes place between 8 and 13 weeks, but at 11 weeks the septum may still be very thin.

Only five cases mentioned in the literature could be inserted into table 5, because in the other cases it was not possible to make a fairly correct estimate of the age of the animal. The data from Perrault (1783; $58 \mathrm{~cm}$, foramen open), Buffon Daubenton (1799; $77 \mathrm{~cm}$, ductus open), Meckel (1831; young, foramen and ductus open), Parsons (1743 ; very young, foramen open), Mayer (1839; four animals $80 \mathrm{~cm}$, foramen and ductus open; 1 animal $80 \mathrm{~cm}$, foramen open, ductus closed), Portal (1683; young, fora- 
men open, ductus closed), Mayer $(1839 ; 85 \mathrm{~cm}$, foramen open, ductus open; $85 \mathrm{~cm}$, foramen closed, ductus open) and Vrolik (1822;88 cm, foramen open, ductus closed), however, show that they fit quite well into the supposition that ductus and foramen. close in animals with a body length between 82 and $92 \mathrm{~cm}$, i. e. : between 8 and 13 weeks after birth. Vrolik $(1822,88 \mathrm{~cm})$, Marschner $\left(1901,108 \mathrm{~cm}, 1 \frac{1}{2}\right.$ year), Mayer $\left(1839 ; 115 \mathrm{~cm}, 1 \frac{1}{2}\right.$ year) and Albas (1802; sexually mature) found a closed foramen and a closed ductus in animals older than 13 weeks. Not in accordance with these facts are the data of Owen $(1831 ; 75 \mathrm{~cm}$, foramen open, ductus closed), Mayer (1839; $155 \mathrm{~cm}$, old, foramen open, ductus closed) and Kulmus (1721; sexually mature, foramen and ductus open).

The data with regard to the umbilical artery and vein are exactly the same as in the Common Porpoise.

\section{Other Pinnipedia.}

Although several colleagues in the U. S. A., in England and in Norway took great trouble in collecting hearts of a number of different pecies of Seals and Sea lions, the number of data that give exact information about the time of closure of the ductus. arteriosus in Pinnipeds, other than the Common Seal, is still very small. There was especially very little material concerning the younger stages of extrauterine life. Nevertheless, especially the following data from table 6 may give us useful indications abou the closure of the ductus:

a) In a California Sea Lion pup of 1 month the ductus Botalli showed a very narrow lumen and not a wide lumen as would be found in a Common Seal pup of the same age.

b) Three Northern Fur Seal pups, resp. 2-4 weeks, 4-6 weeks and 4-6 weeks old, had a completely closed ductus, whereas in Common Seals and Porpoises the ductus is still open at that age.

c) In a Hooded Seal pup of about 10 days the lumen of the ductus was alleady very narrow.

d) The heart of a very young Walrus showed a completely closed ductus Botalli.

e) Other Seals and Sea lions with an age of 3 -4 months, or animals that were indicated as sexually immature, never had an open ductus. If the closure of the ductus was retarded, it cer- 
tainly would still have been open at this age in animals of that size.

Although these data are as yet very scanty, they give a clear indication that in Pinnipeds, other than the Common Seal (or at least in the species that could be dealt with), the duetus arteriosus closes anatomically shortly after birth, probably between the $2 d$ - כ㙂 week.

The ductus arteriosus of the other Pinnipeds had about the same length as in the Common Seal. In the California Sea Lion it had a length of about $2,5 \mathrm{~cm}$. In two hearts of the California Sea Lion a small patch of sclerotic, but not calcified, tissue was found in the wall of the pulmonary artery. In the Northern Fur Seal indications were found that the ductus begins to close at its pulmonary end.

In some hearts of 5 weeks old pups of the Northern Fur Seal there was still a small opening in the foramen ovale. Examination of all the other animals, however, showed that generally the closure of the foramen ovale is complete very shortly after birth.

Q. Sirenia.

The following data bear upon the elosure of the embryonic pathways in the heart of Sirenia:

a) Halicore dugong Erxleb.

Three sexually immature animals ; foramen and ductus closed (Owen, 1868).

Young animal, foramen closed (Home, 1823).

Young animal, foramen and ductus closed (Raffles, 1820).

Animal of unknown age, foramen closed (Rapp, 1837).

Animal of unknown age, foramen closed (Huxley, 1866).

b) Manatus latirostris (Harlan).

$136 \mathrm{~cm}$ long, young male, foramen closed (Vrolik, 1852).

Young animal, ductus elosed (Beddard, 1897).

Adult animal, duclus elosed (Beddard, 1897).

c) Manatus inunguis Natt.

16 years old male, ductus and foramen closed (Zoo Amsterdam, 1943). 
This very scanty material gives at least an indication that in Sirenia foramen ovale and ductus Botalli close during the early stages of extrauterine life.

\section{IV. - Comparison with terrestrial Mammals}

\section{Foramen ovale.}

It is generally accepted that the foramen ovale of terrestrial mammals is closed by its valve because the expansion of the lungs at birth causes an increase in the pressure of the blood in the left atrium. In horses and cattle the valve is firmly attached to the borders of the foramen in about 15-20 days (Ottaway, 1944), but one or two very small openings may persist in a certain percentage of the animals until a higher age. Chaussé (1916) and Steger (1927) have shown that in $18 \%$ of 8 months old pigs the foramen is still completely open and that in $23 \%$ it still has some small openings. In all animals completely closed foramina are found only after an age of about 3 years. Chaussé (1916) and Stroh (1923) found that in $23 \%$ of $\frac{1}{2}-1 \frac{1}{2}$ years old cows the foramen still showed some small openings. Franklin (1946) describes a completely open foramen in a lion cub of 9 days and the same was found in resp. 4 and 8 days old calves of the Bactrian Camel, dissected at the Zoological Laboratory at Amsterdam. Fawcett (1901) and Patten (1931) state that $20 \%$ of adult men still have some small openings in the foramen, whereas Kehrer (1867) says that the closure of the foramen is complete at the age of 12 days in man and rabits, at the age of 3 weeks in horses and dogs and at the age of 1-2 years in Ruminanis.

All the above mentioned facts confirm the conclusion of Slijper (1936) that with regard to the closure of their foramen ovale aquatic mammals do not differ from their terrestrial relatives, with the exception of the Common Seal in whick the closure of the foramen is retarded.

\section{Ductus Botalli.}

The authors of several recent publications have shown that in terrestrial mammals the lumen of the pulmonary arteries increases already before birth, as an adaptation to the amount of blood that must pass these vessels immediately after birth. During the last period of intrauterine life the aorta and the pulmonary arteries continue to increase in diameter because the fœtus grows, but 
the ductus arteriosus stops growing. Consequently the diameter of the ductus decreases in proportion to that of the aorta and the pulmonary artery.

At the first respiratory movements, and the expansion of the lungs after birth, the musculature of the ductus arteriosus contracts and the ductus is physiologically closed. It is generally accepted that in the living animal the ductus remains closed, even if there is still a wide lumen in the dead animal, due to relaxation of the musculature after death. It is also generally accepted, however, that under certain circumstances the musculature may relax in the living animal during a shorter or longer period. Because after birth the pressure in the pulmonary artery is much lower than in the aorta, the blood flows through the temporarily open ductus from the aorta to the pulmonary artery.

Shortly after the physiological closure of the ductus the histological strueture of its wall undergoes some changes that ultimately lead to the anatomical closure of the vessel (see sub $\mathrm{V}$ ). During this process the lumen of the vessel is gradually narrowed and it may be accepted that, if the ductus may still open under certain circumstances, only a negligeable quantity of blood will pass through, at least in the later part of this period. At the end of the process the ductus has become a solid ligament, but it is. already called closed, if at a certain point the lumen has completely disappeared.

In man the moment of physiological closure of the ductus is. determined by Reynolds (1957) at 1-2 minutes, by Barclay c.s. (1938) at one hour and by Eldridge c. s. (1954) and Harman and Herbertson (1938) at 3 days after birth. According to Odé (1951) the anatomical closure is a fact at 8-60 days after birth. Harman and Ilerbertson (1938) have determined this moment at 3 weeks, Melka (1926) says that the ductus closes at 5 months, whereas Scammon and Norris (1918) found that 2 weeks after birth $2 \%$ of the individuals had already a closed ductus, four weeks after birth it was found closed in $11 \%$, at the age of $3 \frac{1}{2}$ months in $82 \%$ and at the age of 1 year in $95 \%$ of the individuals.

The moment of physiological closure in sheep was determined by Barclay c.s. (1938) at 1 minute, by Barclay c.s. (1941) at 3-4 minutes, by Barcroft (1947) at 4 minutes. Dawes c. s. (1955 a) state that it may be patent for many hours after birth and that during that time $1 / 4-2 / 3$ of the pulmonary blood may pass through the ductus. This statement is in contradiction to the generally 
accepted supposition that it is the aortic blood that will flow through the ductus. Beattie (1939) also supposes that, in an abnormal case of open ductus Botalli in an adult sheep, the blood flowed from the pulmonary artery to the aorta, but in this case there was also a patent foramen ovale. Barclay c.s. (1941) describe one case in which the ductus was intermittently open and closed from 7 to 29 minutes after birth.

According to Barclay c.s. (1945) the physiological closure of the ductus in the goat occurs 9 minutes after birth.

Everett and Johnson $(1950,1951)$ found that the ducius of the dog begins to close not before one hour after birth. Nine hours after birth there is still a distinct lumen and even during the third day the flow of blood through the ductus still might be considerable. The anatomical closure was determined at the 18 th day after birth. This is in accordance with Strassmann (1894), who found an open ductus in a 15 days old dog.

According to Kennedy and Clark $(1941,1942)$ the ductus of the Guinea pig closes physiologically between 4 and 10 minutes after birth. Harman and Herbertson (1938) found that at the age of 24 hours no blood flows through the ductus and that it is anatomically closed at the age of 7 days.

In the rat the lumen has disappeared after 14 hours and there is a complete liganent after ten days (van Ingen, 1957). Complete obliteration of the lumen was found by Strubelt (1925) in the cow at an age of 9 months. Miall and Greenwood (1879) found a very distinct lumen in the ductus of a several years old Indian Elephant and Mryer (1847) found the same in a semi-adult animal of this species. A narrow lumen was found in the ductus of 10 days, $1 \frac{1}{3}$ year and 3 years old lions by Schiller (1959), but 19 other animals, aged between 3 months and 15 years, had a completely closed ductus. Franklin (1947) found an open ductus in a 9 days old cub.

The author of this article found a widely open ductus in a 4 days old calf of the Bactrian Camel. In an 8 days old calf the lumen had already narrowed but it may be supposed that a fairly large amount of blood still could flow through. Candaele et Ghys (1958) found an open ductus in a 14 days old Okapi. In the horse the ductus closes comparatively early, but Müller (1868) describes an abnormal case of an 11 years old animal with a paten ductus. 
To sum up, the following average ages of anatomical closure of the ductus Botalli may be stated :

Terrestrial mammals

Guinea pig

Rat

Dog

Man

Lion

Cow

Elephant

7 days
10 days
18 days
$2-12$ weeks
$1-3$ months?
$2-8$ months?
several years?

Common Seal

Common Porpoise

Otiner Delphinids,

Baleen Whales, ap to 13 month

several years?
Aquatic mammets

The first conclusion to be drawn from these data is, that apparently the absolute size of the animals plays an important part in the process of anatomical closure of the ductus. Probably it is the size of the ductus itself that determines the speed of obliteration of the lumen. This can easily be understood from the fact that there are no vasa vasorum in the inner part of the media and in the intima of the ductus arteriosus (Kennedy and Clark, 1941). From the moment that the flow of blood through the lumen of the ductus has ceased, the supply of oxygen and other material required for the activity of the tissues in the inner part of the ductus during the process of closure, fully depends on the vasa vasorum in the onter part of the media and in the adventitia. The greater the distance between these vasa vasorum and the inner lining of the ductus, the more difficult this supply will be and the lesser the activity of the tissues. Consequently the closure of the ductus Botalli will take much more time in a large than in a small animal.

The second conclusion to be drawn is that, when the absolute size of the animals is taken into consideration, the closure of the ductus arteriosus in all Cetaceans and in the Common Seal is markedly retarded as compared with their terrestrial relatives. In the other Pininipeds, however, there is no retardation at all, and the anatomical closure of the ductus may be complete even in a shorter time than in terrestrial mammals of the same size.

\section{V. - HISTOLOGICAL STRUCTURE OF THE DUCTUS ARTERIOSUS BOTALLI}

Kehrer (1867), Pöllot (1909) and Melka (1926) have already shown that in man and other terrestrial mammals the histological structure of the ductus arteriosus Botalli differs from that of the aorta and the pulmonary artery. The ductus arteriosus is a museular artery, whereas in the majority of the mammals the aorta and 
the pulmonary artery have elastic walls. Swensson (1939) and Odé (1951) found that in man and in the rabbit the wall of the ductus consists of an intima with many smooth muscle fibres and fine elastic fibres, a well developed elastica interna, a media with comparatively few elastic fibres and an adventitia with collagenous and elastic fibres. Winternitz c.s. (1938) and Peckholz (1956), have shown that vasa vasorum are only found in the adventitia and in the outer part of the media, but that they are completely lacking in the inner part of the media and in the intima.

The contraction of the musculature of the ductus at birth causes the proliferation of cushion-like thickenings of the intima into the lumen of the vessel. This causes the closure of the lumen (Peckholz, 1956 ; Danesino c.s., 1959 ; Sciacca c.s., 1954). By necrosis of the muscular tissue and increase of the collagen and elastic fibres, the wall of the vessel is ultimately iransformed into a ligament (Odé, 1950, 1951).

The examination of a great number of cross sections of the ductus Botalli in foetal, newborn, young and adult specimens of the Blue Whale, the Fin Whale, the Common Porpoise and the Common Seal has shown that in these aquatic mammals the histological structure of the ductus Botalli and its mode of obliteration after closure are essentially the same as in terrestrial mammals. In foetuses the intima comprises about $10 \%$, the media about $70 \%$ and the adventitia about $20 \%$ of the diameter of the wall of the vessel. In young and adult subjects these percentages are resp. 40, 30 and 30 . The inner part of the intima, which protrudes into the lumen, consists of collagenous fibres and muscle fibres with almost no elastic tissue, whereas the outer part of the intima mainly consists of concentric elastic fibres and lamellae. The media contains but little elastic tissue, but the adventitia is mainly built up of heavy developed concentric elastic lamellae. In the media of older animals the number of muscle fibres has decreased whereas the number of elastic fibres has increased. Vasa vasorum are only found in the adventitia and in the outer part of the media, just as in terrestrial mammals. Walmsley (1938) described the histological structure of the ductus arteriosus in an about 6 months old foetus of the Fin Whale. His description of the intima agrees quite well with our findings, but his statement that the media contains only a few muscle fibres and that it had almost the same structure as the adventitia, conld not be confirmed. 


\section{VI. - FACTORS BY WHICH THE CLOSURE OF TYE DUCTUS ARTERIOSUS IS CAUSED IN TERERTTRIAL MAMMALS}

Reynolds c.s. (1954), Reynolds (1956), Barclay c.s. (1941), Everett and Johnson (1950) and other authors have shown that the pumonary arterial capillaries of the foetus give a high resistance to the blood, because they are coiled and packed with erythrocytes. Before birth pulmonary periferal resistance is high and so is the pressure in the pulmonary artery. Because, particularly in young foetuses, the pulmonary arteries are insignificant onches of the common stem of these arteries and the ductus arteriosus (Odé, 1951), nearly all the blood from the right ventricle flows through the ductus to the aorta. During the later part of foetal hife the pulnonary arteries increase in diameter but the ductus arteriosus stops growing. At birth the lumen of the ductus is already narrower than the combined lumina of the pulmonary arteries.

At birth the lungs expand gradually but considerably, the pulmonary capillaries expand to the same degree and shorily after birth the presure in the pulmonary stem is lower than in the aorta, just as in adult subjects. The ductus closes physiologically, although for some time a narrow lumen may remain (Born, 1956). Dawes (1955) has shown that through this lumen blood flows from the aorta to the pulmonary artery, which causes a typical cardiac menmur. If in abnormal cases in man the ductus Botalli remains open, blood also flows from the aorta to the pulmonary artery (Kroll, 1959). Only in cases of a so called atypical parent ductus arteriosus, there is as a reaction on the open ductus such a heavy pumonary hypertension, that blood flows from the pumonary artery to the aorta. In the first case there is an overloading of the left ventricle, in the second case an overloading of the right ventricle, mostly connected with hypertrophy of the ventricular walls. Barclay c.s. (1938, 1941) and Kennedy ard Clark (1941) have shown that the physiological closure of the ductus is a reversible process. The ductus may open from time to time. Moreover at first the closure of the Iumen is not complete, as has also been stated above.

Kennedy and Clark $(1941,1942)$ found that the ductus of the Guinea pig is closed when the lungs expand actively or passively. If respiration ceased the ductus opened again. Yet it were not the 
respiratory movements that caused the closure of the ductus because it remained open if nitrogen was aspired in stead of normal air. It appeared that the closure of the ductus was not caused by pressure changes in the arteries but by the amount of oxygen saturation of the blood. This was clearly demonstrated by the experiments of Hefner and Clark (1949), Ossiladore (1954), Record and McKeown (1955 a, 1955 b) and Born (1956), whereas Barcroft c.s. (1940) had already shown that the oxygen saturation of the carotid blood in the lamb rises markedly within a few minutes a ferter birth.

Everett and Johnson (1951) and Born (1956), however, found some indications that pulmonary pressure may not entirely be excluded as a cause for closure of the ductus. It is a well known fact that in normal subjects anoxia increases pulmonary vascular resistance and as a consequence causes a rise in pulmonary arterial pressure (Best and Taylor, 1950). Consequently it is still possible that a low oxygen content of the blood causes a bigh pulmonary arterial pressure and that the ductus opens again if the pressure in the pulmonary artery is higher than in the aorta, i.e. if the foetal pressure relations appear again.

In ary case it is quite clear now that certain respiratory difneulties may prevent the closure of the dnctus arteriosus. This is entirely confirmed by the investigations of Record and McKeown (1953). In 633 cases of patent ductus arteriosus in man they found that a considerable proportion of these cases showed a history of foetal distress at birth (asphyxia, pnevmonia, long labour etc.). There was a much higher incidence of foetal distress than in children with a normal ductus $(30-45 \%$ against $5-15 \%)$. Consequently there is a good deal of evidence that asphyxia at birth may delay closure of the ductus arteriosus. Record and McKeown (1953) hold that respiratory embarrasment of the foetus and newborn may not always be so transient as it appears. They may even last for days rather than minutes. This opinion about the closure of the ductus is confirmed by Alzamora c.s. (1953), who found in people living in Peru above $3000 \mathrm{~m}$ a significantly higher number of cases of patent ductus Botalli than in people living in the lowlands. 
The facts mentioned in the preceding paragraph suggest that, if during the period immediately after birth respiratory difficulties occur, this may result in an - eventually periodical - re-opening of the ductus arteriosus and that this may cause a considerable retardation of the anatomical closure of the ductus. Such respiratory difficulties may be expected in Cetaceans and Sirenians, the young of which are born in the water and consequently swim and dive immediately after birth. It is very difficult to say something about the nature of these respiratory embarrassments. It may be supposed that during the first days of life shortage of oxygen occurs in the blood if the animals dive too long. It may also be supposed that the pulmonary resistance and the pressure in the pulmonary artery rise when respiratory movements stop during diving and hydrostatic pressure is exerted on the thorax. Unfortunately nothing is known of what happens in this respect in man and other terrestrial animals during diving. A small indication of a rise of pulmonary pressure during diving, however, can be found in the work of Schott (1922).

On the other hand the possibility may not be excluded that the forced expiration, that occurs especially in Cetaceans (Slijper, 1958) and that may be compared with the Valsalva-effect, causes a rise of pulmonary pressure at every expiration. Oscillations in pulmonary pressure probably play a more important part in Cetaceans than in Pinnipeds, because Cetaceans always dive with their lungs maximally filled with air, whereas Pinnipeds mostly dive after expiration.

Bartholomew (1954), Lockley (1954), Grzimek (1956) and Laws (1956) have observed that resp. The Northern Elephant Seal (Mirounga angustirostris (Gill)), the Grey Seal (Halichoerus grypus (Fabr.)), the Harp Seal (Phoca groenlandica Erxleb.) and the Elephant Seal (Mirounga leonina $(\mathbb{L}$.)) expire before diving. Harnisch (1937), however, remarks that Pinnipeds may also dive with their lungs filled with air but according to Hewer (verbal communication) and Mohr (1955), Common Seals (Phoca vitulina I.) mostly dive after expiration, especially if they go down for a deep dive.

If the above mentioned causes may explain the retardation in the closure of the ductus Botalli in Cetaceans it still must be 
explained why in the Common Seal the process in this respect is exactly the same as in the Whales and Dolphins, whereas in the other Pinnipeds it is the same as in terrestrial mammals. The explanation of this difference may be found in the behaviour of the young after birth.

Just like all other Pinnipeds the young of the Common Seal (Phoca vilulina L.) are born on land (Slijper, 1956, 1960). On the Netherlands coast the young Seals are born on the sand banks, when these are dry at low tide. At high tide the banks are overflown by the sea water and if the weather is stormy even at low tide the banks may be hardly dry. Consequently the newborn seal is obliged to swim at least 6-8 hours after birth, but it may happen that they must do so already 1-2 hours after they are born (van Haaften, 1940). Venables and Venables (1955) observed that on the Shetland Isles during the first days after birth the young do not even come on land; they are nursed in the water. J. L. van Haatten saw that a 15 minutes old animal swam perfectly, and Heinroth (1958) and Junker (1940) stated that in the Berlin $\mathbb{Z} 00$ and the Aquarium at Wesermünde the young went into the water almost immediately after birth. At the coast of British Columbia Fisher (1952) observed that the pups swam a few hours after birth and that they could dive until 1 minute. These facts are quite in accordance with the observations of Allen (1880), Stocker (1933), Bertram (1940), Mohr (1952, 1955) and Kenyon and Scheffer (1953).

According to Scheffer (1958) and Mohr (1959) the young of the Monk Seal (Monachus monachus (Hermann)) go into the water on the same day on which they are born and this phenomenon has also been observed in the Hooded Seal (Cystophora cristata (Erxleb.)) according to a verbal communication of Prof. J. T. Ruud (Oslo). Unfortunately no hearts of the Monk Seal were available, whereas those of the Hooded Seal only showed that in a 7-14 days old pup the ductus Botalli was open and that it was closed in animals older than 1 year. This gives no useful indications about a possible retardation of the closure of the ductus.

Bertram (1940) says that Crabeater Seals (Lobodon carcinophagus Jacquinot et Pucheran) go into the water at the 3d-4th day after birth. The behaviour of the Grey Seal (Halichoerus grypus (Fabr.)) appears to be very variable. Davies (1949) observed that at Ramsey Island some pups swam already a few hours after birth. 
whereas others did not enter the water before they were 10-14 days old. Hewer (1957) describes that at the Hebrids most of the pups do not go into the water before the age of 2 weeks. They are only seen in shallow water and swim with the aid of the mother. In his most recent publication on this species Hewer (1960) points to the fact that most of the Grey Seal pups stay on land until they have moulted at an age of about 3-4 weeks. Allen (1880) and Haglund (1956) state that the pups do not swim before the moult is completed at an age of about 5 weeks (see also van Haaften, 1940).

In all other Pinnipeds the time the pups stay on land before entering the water for the first time after birth, is much longer than in the Common Seal, the Monk Seal, the Hooded Seal and the Crabeater Seal. With reference to the California Sea Lion (Zalophus californianus (Lesson)) Gijzen (1956) states that the newborn animals drown if they go into the water. In the Leipzig Zoo they entered the water for the first time at the age of 18 days and according to Allen (1880) pups do not swim before they are 4-5. weeks old. Rowley (1929) says that the newborns cannot swim. If they are brought into the water they float by heavy leaps of their flippers. In a letter A. L. Kelly writes that the pups are capable of swimming at once but they do so rather weakly during about 4 months.

The Harp Seal (Phoca groenlandica Erxleb.) occasionally goes into the water at an age of $2-6$ days but the majority of the pups do not do so before the wool coat is completely or partially discarded, i.e. : at 14-28 days after hirth (Sivertsen, 1341 ; Dorofejev, 1936; Freuchen, 1959). Lindsey (1937) saw some young of the Weddell Seal (Leptonychotes Weddeli (Lesson)) swimming and diving in a shallow pool at an age of 8-20 days. Mansfield (1958) says that only a few of the pups will take to the water at an early age (7-13 days). According to Bertram (1940) they generally do not enter the water before they are about three weeks old.

In the Northern Fur Seal (Callorhinus ursinus (L.)) the time at. which the young enter the water is determined at several weeks by Day (1949), at 6 weeks by Allen (1880), at 4 weeks by Osgood (1914), at 3-4 weeks by V. B. Scheffer (personal communication) and at 3 weeks by Bartholomew (1959). Wilke (1960) writes that the pups can swim from the moment of their birth, but does not explicitely say that they always do so. He states that at first they 
swim rather arkwardly with their head high our of the water. This means obviously that they do not dive.

With regard to the South American Sea Lion (Otaria byronia (de Blainville)) Dr. A. C. V. van Bemmel and Mr. van Doorn write that a young animal in the Blijdorp Zoo at Rotterdam did not enter the water before it was 5 weeks old. According to Allen (1880) the Ringed Seal (Phoca hispida (Schreb.)) enters the water for the forst time at the age of 6 weeks. Freuchen (1959) states that young pups drown when they try to swim and that it generally takes a long time before they enter the water. I. A. Mc Laren writes in a letter : " at least several days 》, and makes the same statement about the Bearded Seal (Erignathus barbatus (Erxleb.)).

Kenyon and Scheffer (195:) say that it takes several weeks before the young of the Steller Sea Lion (Eumetopias jubata (Schreb.)) go into the water. Daetz (1959) writes that they do so for the first time in the 2nd week, but that they cannot dive before they are $3-4$ weeks old. According to a communication in the Nürnberg Zoo Sea bears (Arctocephalus pusillus Schreb.) cannot swim before they are several weeks old. About the Elephant Seal (Mirounga leonina (L.)) Laws (1956) writes: "They do not usually enter the water until they are over 34 days old. During the first weeks they go only in very shallow water. Occasionally, however, they go into the water at an earlier date. The youngest seen swimming was 2 days old. "Nearly the same can be said of the Northern Elephant Seal (Mirounga angustirostris (Gill)) whose young do not enter the water before they are several weeks or even about 2 months old (Bartholomew, 1942). Buckley (1958) writes about the Walrus (Odobenus rosmarus (L.)) that the young are capable of swimming immediately after birth, but this does not mean that they usually do so, because M. M. Sleptzov (personal communication) informed me that they do not enter the water before they are three weeks old.

From the information given above, the conciusion may be drawn that with respect to the moment at which they enter the water for the first time after birth, there is a very significant difference between the Common Seal (and also probably the Monk Seal, the Hooded Seal and the Crabeater Seal) on the one hand, and the other Pinnipeds on the other hand. The pups of the first mentioned animals always go into the water almost immediately 
after birth and at that moment they can swim and dive very well. The pups of the other Pinnipeds may be capable of swimming immediately after birth in some species, whereas in other they even will drown if they go into the water. In the species where they are capable of swimming immediately, some young animals may enter the water at an early age (for example 2 days), but the majority of the pups remain on land for several weeks. Consequently with regard to the physiological and anatomical closure of the ductus arteriosus Botalli the Common Seal and the other species that swim immediately after birth, are in the same position as the Cetaceans that are born in the water. The young of the other Pinnipeds are almost in the same position as the terrestrial animals because the majority of the pups remain on land during such a long time that the lumen of the ductus arteriosus may have become already very narrow or that the anatomical closure even has already started before the pups enter the water for the first time.

The biological situation in other aquatic mammals apparently resembles more that in the terrestrial mammals and the majority of the Pinnipeds, than that in the Cetaceans, the Common Seal and some other Pinnipeds. The Otter (Lutra lutra (L.)) is born on land and the young do not enter the water very soon (Stephens, 1957). The Sea Otter (Enhydra lutris $(\mathbb{L}$.$) ) is born either on land$ or in the kelp beds, but the pups are so light that they always remain floating. They even stay floating if the mother dives (Jacobi, 1938 ; Kenyon and Scheffer, 1953). Beavers (Castor canadensis Kuhl) are born on land and if the young go into the water they float just as Sea Otter pups, due to the air in their coat of fur. According to Hinze (1950) the young may go into the water at 4 days but usually they do not so before $2-6$ weeks. Van Doorn (1960) tells about a young entering the water at 9 days and Shadle (1930) about a young who did so already at the 2nd day. The young of the Muskrat (Ondatra zibethica (L.)) stay in the den for at least 14 days and even than they are not at once able to dive (Hoffmann, 1958). The Pigmy Hippopotamus (Choeropsis liberiersis (Morton)) is usually born on land (Slijper, 1960). According to Steinemann (1955) and Sanderson (1958) the young enters the water not before it is at least one week old.

Sirenia are born in the water, but there are some indications that, with regard to their respiration, the young are not quite in 
the same position as the calves of the Cetaceans. In the Florida Manatee (Trichechus manatus latirostris (Harlan)) Moore (1951) observed that the mother carried the newborn on her back during 45 minutes after birth so that the nostrils of the young were constantly above the surface of the water. During the next two hours she also carried the young on her back but then she dived intermittently for short periods. Barbour (1937) saw that during the first week after birth both the father and the mother of a young Manatee pushed it to the surface of the water every $4-5$ minutes, but in a Manatee living in capivity Moore (1957) could not observe this behaviour. At least a part of the young Hippopotamuses (Hippopotamus amphibius L.) is born in the water (Slijper, 1960) and the young are always capable of swimming and diving immediately after birth. Unfortunately nothing is known about the ductus Botalli of the Hippopotamus, whereas the information about the Sirenians is too scanty to draw definite conclusions.

\section{VIII. - SumMary and CONGLUStons}

1. Researches on the closure of the foramen ovale and the ductus arteriosus Botalli in aquatic mammals based on dissections of 53 Common Porpoises (Phocaena phocaena (L.)), 22 Blue and Fin Whales (Balaenoptera musculus (L.), Balaenoptera physalus (L.)), 39 other Cetaceans, 20 Common Seals (Phoca vitulina $\mathbb{L}_{\text {. }}$ ) and 37 other Pinnipeds.

2. Just as in terrestrial mammals the foramen ovale of aquatic mammals closes shortly after birth, with the exception, however, of the Common Seal in which the closure of the foramen is retarded.

3. Anatomical closure of the ductus arteriosus Botalli occurs at an age of 2-5 weeks in Pinnipeds other than the Common Seal, at an age of $8-13$ weeks in the Common Seal, at an age of 4-14 months in the Common Porpoise and in other Delphinidae and at ages up to 13 years in Blue and Fin Whales. A high age of closure probably also oceurs in other Baleen Whales and in the Sperm Whale (Physeter macrocephalus L.).

4. Researches on terrestrial and aquatic mammals have shown that the absolute size of the animal is an important factor in deter- 
mining the time of anatomical closure of the ductus Botalli. This phenomenon ultimately depends on the absolute size of the ductus itself and on the fact that no vasa vasorum are found in the inner parts of its wall (in aquatic as well as in terrestrial mammals).

5. If the absolute size of the animals is taken into consideration, it may be stated that the closure of the ductus arteriosus in all Cetaceans and in the Common Seal is markedly retarded, compared with their terrestrial relatives.

6. Although reliable data about the other Pinnipeds are still very scanty, there are strong indications that in the species involved, there is no retardation in the anatomical closure of the ductus Botalli. The closure may be even complete at an earlier age than in errestrial mammals of the same size.

7. The histological structure of the ductus arteriosus in the foetus and the newborn as well as the histological process of closure of the ductus are the same in aquatic and in terrestrial mammals.

8. Researches on terrestrial mammals have shown that a rise of the oxygen saturation of the blood, which occurs almost immediately after birth, causes the physiological closure of the ductus arteriosus by contraction of its musculature.

9. Shortage of oxygen in the blood and eventually also a rise of the blood pressure in the pulmonary artery may cause a temporary re-opening of the ductus Botalli, which prevents, or at least retards, its anatomical closure. Respiratory difficulties after birth may prevent the anatomical closure of the ductus.

10. Respiratory difficulties, the exact nature of which is not yet known, may occur after birth in all Cetaceans because these animals are born in the water. They swim and dive immediately after birth. Respiratory difficulties also occur in the Common Seal because the pups of these animals are obliged to enter the water very shortly after birth. They also are immediately capable of diving and do so regularly. Consequently it may be supposed that during the period immediately after birth these respiratory 
difficulties cause a temporary re-opening of the ductus arteriosus. This may be regarded as the cause of the retarded closure of the ductus.

11. The pups of practically all other Pinnipeds (for possible exceptions see sub VII) generally do not enter the water before they are $3-4$ weeks old or even older. In some species the pups may be able to swim at an early age, but generally they do not do so, and they never dive at an early age. Consequently respiratory tifficulties, such as are supposed in Celaceans and in the Common Seal, will not occur in these Pinnipeds and consequently the anasomical closure of the ductus is not retarded.

12. Because the conclusions with regard to the "other Pinnipeds $》$, are based on a very small number of reliable data it is highly desirable to collect more material concerning these animals, especially concerning pups younger than three months.

\section{RESUME}

$1^{\circ}$ Cet article résume des recherches sur f'occlusion du trou ovale et du canal artériel de Botal chez les Mammifères aquatiques, basées sur la dissection de 53 Marsouins ( $P h$. phocaena), 22 Rorquals bleus et Rorquals communs (Balaenoptera musculus et $B$. physalus), 39 autres Cétacés, 20 Phoques communs (Phoca vitulina) et 37 autres Pinnipèdes.

$2^{\circ}$ Comme chez les Mammifères terrestres, le trou ovale des Mammifères marins s'obture peu de temps après la naissance, à l'exception toutefois du Phoque commut chez lequel cette occlusion est retarcée.

$3^{\circ}$ L'occusion anatomique du canal artériel de Botal a lieu à l'âge de 2 à 5 semaines chez les Pinnipèdes autres que le Phoque commnn, à l'âge de 8 à 13 semaines chez le Phoque commun, à l'âge de 4 à 14 mois chez le Marsouin et les autres Delphinidés, à des âges s'échelonnant jusqu'à 13 ans chez les Baleines bleues ef les Balénoptères. L'époque d'occlusion est probablement assez reculée chez les autres Baleines et chez les Cachalots.

4. Des recherches sur les Mammifères terrestres et aquatiques ont montré que la taille absolue de l'animal est un important facteur dans l'âge d'occlusion anatomique du canal de Botal; ce phénomène dépend en définitif de la taille absolue de ce canal lui-même et du fait que aucun des vasa vasorum ne se trouve dans les parois internes (aussi bien chez les Mammifères terrestres qu'aquatiques).

$5^{\circ}$ Si l'on prend en considération la taille absolue de l'animal, il faut remarquer que l'occlusion du canal artériel est considérablement retardée chez tous les Cétacés et chez le Phoque commun par rapport aux Mammifères terrestres.

$6^{\circ}$ Bien qu'on ne dispose encore que de peu de renseignements sur les autres Pinnipèdes, nous avons de bonnes raisons de croire que l'occlusion de leur canal artériel de Botal n'est pas retardée. L'occlusion peut être complète chez cenz-ci à un stade plus précoce que chez les Mammitères terrestres de même taille. 
$7^{\circ}$ La structure histologique du canal artériel de Botal chez le foetus et le nouveau-né ainsi que le processus histologique d'occlusion sont les mêmes chez les Mammifères terrestres et aquatiques.

$8^{\circ}$ Des recherches sur les Mammifères terrestres ont montré que l'augmentation de la tension d'oxygène dans le sang qui se produit immédiatement ou presque après la naissance est la cause de l'occlusion physiologique de ce canal par suite d'une contraction de sa musculature.

9० La baisse de tension d'oxygène dans le sang ef éventuellement aussi une surpression du sang dans l'artère pulmonaire peut causer une réouverture temporaire du canal qui retarde ou même empêche son occlusion anatomique. Des diffieutés respiratoires après la naissance sont également susceptibles d'empêcher la fermeture anatomique du canal.

$10^{\circ}$ Des difficultés respiratoires de nature encore inconnue penven survenir après la naissance chez les Cétacés du fait que ces animaux naissent dars l'eau. Ils nagent et plongent immédiatement après la naissance. Des difficultés respiratoires peuvent également survenir chez le Phoque commun car les jeunes sont obligés d'entrer dans l'eau peu de temps après la naissance. Ils sont immédiatement capables de plonger, ce qu'ils font d'ailleurs d'une manière très régulière. Pendant la période suivant immédiatement la naissance, ces difficultés peuvent causer une réonverture temporaire du canal artérien, occasionnantun retard à l'occlusion.

$11^{\circ}$ Les jeunes de presque tous les Pinnipèdes (à l'exception de ceux mentionnés au paragraphe VII) n'entrent généralement pas dans l'eau avant d'être âgés de 3 à 4 semaines au minimum. Chez quelques especes, les jeunes sont capables de nager avant cet âge, mais ne le font généralement pas ế en tous cas ne plongent jamais. En conséquence, des difficultés respiratoires, telles qu'elles soni supposées exister chez les Cétacés et le Phoque commun, n'inqerviennent pas chez ces Pinnipèdes et par conséquent l'ocelusion anatomique du canal n'est pas retardée.

$12^{\circ}$ Du fait que nos conclusions concernant les « autres Pinnipedes 》 soni basées sur un très petit nombre de renseignements précis, il est évidemment souhaitable que plus de matériel concernant ces espéces soit collecté, spécialement des jeunes âgés de moins de 3 mois.

\section{LITERATURE}

Aubrers, J. A. (1802). - Zergliederung des Seehundes. Beitr.z. Anat. w. Physiol. (J. A. Albersi, Bremen.

ALEN, J. A. (1880). - Wistory of North American Pinnipeds. Dept. Int. U. S. Geol. Geogr. Sarvey Territories Misc. Publ. 12, Washinglon.

AIzAMora, V. c. s. (1953). - - On the Possible Influence of Great Altitudes on the Determination of Certain Cardiovascular Anomalies. Pediatrics, 12, p. 259.

Anoersor, 3. (1878). - A Monograph of the two Celacean Genera Platanista and Orcella. Anat. Zool. Res. two Exp. to Western Yunnan, p. 357, London.

BApBoun, Th. (1937). - The Birth of a Manatee, Journ. Mammalogy, 18, p. 106 
Bsactar c. s. (194l). - Stilies on the Fetal Girculation and of Goptain Changes that take place after Birth. Americ. Journ. Anat., 69, 1. 383 .

Barglay, A. E., J. Barghoft, D. H. Barroy and K. J. Franketh (1938). Closing of Ductus Arteriosus. Jourit. of Physiology, 93, p. $36 \mathrm{P}$.

Barciay, A. F., K. J. Frayklin and M. M. L. Prighard (1945). - The Foetal Circulation. Blackwell Sci. Publ. Oxford.

Bargroft, J. (1917). - Researches on Pre-nalal Life. Ch. C. Thomas. Springfield.

BArGafr, J., J. A. Kennedr and M. F. Masor (1938). - The Relation of the Vagus Nerve of the Ductus Arteriosus in the Guinea Pig. Journ. Physiology, 92, p. 1 P.

Barkow, H. G. L. (1862). - Das Leben der Walle in seiner Beziehung zum Athmen und zum Blullauf. Breslau.

Baprofonew, G. A. (1942). - Reproductive and Social Behavior of the Northern Elephant Sea1. Univ. Calif. Publ. Zool., 47, p. 372.

Bartholonew, G. A. (195) - - Body Temperature and Respiratory and Heart Rates in the Northern Elephant Seal. Journ. Mammalogy, 35, p. 211.

Bartholonew, G. A. (1959). - Mother-young Relations and the Maturation of Pup Behaviour in the Alaska Fur Seal. Animal Behaviour, 7, p. 163.

Beatrie, F. J.R. (1939). - Note on a Case of Patent Ductus Arteriosus and Patent Foramen Ovale in a Mature Sheep. Journ. Anatomy, 73 , P. 662 .

Beavregard, H., et R. Boulart (1897). - Recherches anatomiques sur les Balénides. Nouv. Arch. Mus. Hist. Nat. Paris, Sér. 3, t.9, p. 95.

Beddard, F. E. (1897). - Notes upon the Anatomy of a Manatee lately living in the Society's Gardens. Proc. Zool. Soc., p. 47.

Bertram, G. G. L. (1940). - The Biology of the Weddell and Crabeater Seals. British Graham Land Expedition 1934-37, Scient. Reports, Vol. 1, p. 1 .

Best, C. Ul., and N. B. Taylor (1950). - The Physiological Basis of Medical Practice, 5th $\mathbb{E}$. Baillière, Tindall, Cox, London.

Bory, G. V. R., G. S. Dawes, J. C Mott and B. R. Revrick (1955). - The Mochanism of Constriction of the Ductus arteriosus in the Newborn Lamb. Journ. Physiol., 128, p. 28P.

Bonn, G. V.R., G. S. Dawes, J. G. Mott and B. R. Rennick (1956). The Constriction of the Ductus arteriosus caused by Oxygen and by Asphyxia in Newborn Lambs. Journ. Physiol., 132, p. 304.

Bouvizr, E. L. (1889). - Les Cétacés souflleurs. Thèse conc. agrég. Ecole sup. Pharmacie, Paris. 
BouviER, F. L. (1892). - Observations anatomiques sur l'Hyperodon rostratus lilljeborg. Ann. Sci. Nat. Ser. 7, Zool., t. 13, p. 259.

Buckszr, J. L. (1958). - The Pacific Walrus. U. S. Fish and Wildlife Service Special Scient. Report. Wildlife 41 , Washington DC.

Buffon et Daubenton (1799). - Histoire naturelle générale et particuhière. Amsterdam.

Burmeister, H. (1869). - Descripcion detallada del Epiodon australe. An. Mus. Publ. Buenos Aires, 1, p. 312.

Burmenster, H. (1869a). - Descripcion de cuatro especies de Delfinides de la costa Argentina. Anal. Mus. Publ. Buenos Aires, 1, p. 367.

Canmagle, G. et A. Grys (1958). - Quelques observations sur le ccur de l'Okapi. Bull. Soc.Roy. Zool. Anvers, 7.

Carte, A., and A. Macalistre (1868). - On the Anatomy of Balaenoptera rostrata. Phil. Trans. R. Soc. London, 158, p. 201.

Grausse, P. (1916). - Recherches sur la persistance du trou de Botal chez quelques animaux domestiques. Compt. Rend. Ac. Sci. Paris, 162, p. 480 .

GLELAND, J. (1884). - Notes on the Viscera of the Porpoise and White Beaked Dolphin. Journ. Anat. Phys., 18, p. 327.

Covisr, G. (1805). - Leçons d'Anatomie comparée, 7, Paris.

Guvien, G. (1836). - Histoire naturelle des Cétacés. Paris.

Datrz, G. M. (1959). - Alaskan Challengers of the Sea. Natural History, 68, p. 335 .

Danesino, V. L., S. M. R. Pernoldo, and I. H. Remman (1955). - Comparative Histological Structure of the Human Ductus Arteriosus. Anat. Rec., 121, p. 801.

Davies J. L. (1949). - Observations on the Grey Seal at Ramsey Island. Proc. Zool. Soc., 119, p.673, 1949.

Dawes, G. S., J. C. Motr and J. G. Widdicombe (1954). - The Foetal Circulation in the Lamb. Journ. Physiol., 126, p. 563 .

DAwes, G. S., J. G. Mot'T and J. G. Wrodrcombe (1955). - The Cardiac Murmur from the Patent Duclus Arteriosus in Newborn Lambs. Journ. Physiol., $128, \mathrm{p} .344$.

Dawes, G. S., J. C. Motm and J.G. Widdrcombe (1955a). - The Patency of the Ductus Arteriosus in Newborn Lambs. Journ. Physiol., 128, p. 361 .

DAY, A. M. (1949). - Old Man of the Pribilofs. U. S. Dept. Inst. Fish and Wildlife Service, Wildlife Leaflet 323 , Scient. Monthly, 68, No. 5.

Doonn, A. C. van (1960). - Ouders die hun kinderen op de handen dragen. Blijdorp Geluiden, $8, \mathrm{p} .5$.

Dorofesey, S. W. (1936). - Materials on the Study of the Early Life of the White Sea Harp Seal. Akad. Nauk USSR, Moskou. 
ELDRIDGe, F. L. H. W. Hultgren and M. E. Wigmore (1954). - The Physiologic Closure of the Ductus Arteriosus in Newborn Infants. Science, 119, p. 731 .

- Everetr, N. B., and R. J. Johnson (1950). - Use of Radioactive Phosphorus in Studies of Fetal Girculation. Americ. Journ. Physiol., 162, p. 147.

Everett, N. B., and R. J. Johnson (1951). - A Physiological and Anatomical Study of the Closure of the Ductus Arteriosus in the Dog. Anat. Record, 110, p. 103.

FAwcerT, F. (1901). - The Frequency of an Opening between the Left and Right Auricles at the Seat of the Foetal Foramen Ovale. Journ. Anat. Phys., 35, p. 67.

Fisuer, H. D. (1952). - The Status of the Harbour Seal in British Columbia with Particular Reference to the Skuna River. Bulletin Fish. Research Board of Canada, 93.

Frsmeir, K. J. (1946). - Patent Foramen Ovale and Ductus Arteriosus in a Lion Cub. Journal of Anatomy, 80, p. 209.

Frevcher, P. (1959). - The Arctic Year, London.

GELDEREv, Chr. van (1928). - De foetale bloedsomloop en de veranderingen daarin in aansluiting aan de geboorte. Geneesk. Bladen, $26^{\circ}$, p. 351 .

Grax, R. W. (1934). - Whales and Caisson Disease. Nature, 134, p. 853

Grzimer, B. (1956). - 20 Tiere und ein Mensch. Kindler Verlag, München.

GIJZEN, A. (1956). -- Over de Zeehond. Zoo, 22, p. 13.

HAAFter, J. L. van (1960). - Harbour Seal and Grey Seal in Dutch Coastal waters. Trans. IV Congr. Int. Union Game Biol. Meded. I.T.B.O.N., $50, \mathrm{p}, 64$.

MAGLUNo, B. (1956). - In Nordischer Wildnis, Parey, Berlin.

Harman, M. F., and J. E. Herbertson (1938). - Concerning the Postnatal Obliteration of the Umbilical Vein and Arteries, the Vitellin Vein and Artery and the Ductus Arteriosus in the Guinea Pig. Transact. Kansas Acad. Science, 41, p. 369.

Ilarnsch, 0. (1937). - Beobachtungen und Gedanken über den Atemrhythmus der Pinnipedier. Zool. Anz., 117.

Harpison, R. I. (1960). - Reproduction and Reproduclive Organs in Common Seals in the Wash. Mammalia, 24, p. 372 .

Havinga, B. (1933). - Der Seehund in den holländischen Gewässern. Tijdschr. Ned. Dierk. Vereen. (3), 3. p. 79.

Hanroth, $\mathbf{K}$. (1958). - Über Seehundgeburten im Zoologischen Garten Berlin. Zool. Garten, NF 22, p. 196. 
Herrer, L., and S. L. Chark (1999). - Further Observations on the Mechanism of Closure of the Ductus Arteriosus in the Guinea Pig. Anat. Record, 103, p. 542.

Hepbur, D. (1896). - Halichoerus gryphus, the Grey Seal. Journ. Anat。 Phys., 30, pp. 413, 488.

Hewer, H. P. (1957), - A Hebridean Colony of Grey Seals. Proc. Zool. Soc., 128, p. 23.

HEWER, H. R. (1960). - A Preliminary Account of a Colony of Grey Seals in the Southern Inner Hebrides. Proc. Zool. Soc., 134, p. 157.

Hinze, G. (1950). - Der Biber. Akademie Verlag, Berlin.

Horfman, M. (1958). -- Die Bisamratte. Leipzig.

Houmes, R. L. (1957). - The Rabbit Ductus Arteriosus. Nature, 180 , p. 1058.

Foums, R. L. (1958). - Some Features of the Ductus Arteriosus. Journ. of Anat., 92, p. 304.

Howe, E. (1823). - Lectures of Comparative Analomy. Vol. 3 en 4. London.

Howes, G. B. (1879). - On some Points in the Anatomy of the Porpoise. Journ. Anai. Phys, 14, pp. 467, 1879.

Huxuey, J. (1866). - Lectures at the Royal College of Surgeons. Lancet, 1 , pp. 180,381 .

IuLE, J. E. W. c. s. (1918). - Leerboek der vergelijkende Ontleedkunde van de Vertebraten. Oosthoek, Utrecht.

INGEN, H. C. van (1957). - Les caractères microscopiques de l'oblitération du canal artériel de Bolal. C. R. Assoc. Anat., A4 (Leiden, 1957), p. 923.

JAGsor, J. B. S. (18:5). - Dissection of a Spermaceti Whale and three other Cetaceans. Boston Journ. Nat. Hist., 5, p. 137.

JaCoBr, A. (1938). - Der Seeotter. Monogr. d. Wildsäugetiere, 6, Leipzig.

JAGEP, B. V , and O.J. Wollexmay (1942). - An Anatomical Study of the Glosure of the Ductus Arteriosus. Americ. Journ. of Pathology, 18 , p. 595.

Jonker, H (1940). - Die Aufucht der Seehunde in den Tiergrotten der Stadt Wesermünde. Zool. Garten, NF 12, p. 306.

KeHrgr, F. A. (1867). - Beiträge zur vergleichenden und experimentellen Geburtskunde, II. Giessen.

KeL LOGG, II. B. (1928). - The Course of the Blood Flow through the Fetal Mammalian Heart. Americ. Journ. Anat., 42, p. 433.

Kenveny, J. A., and S. L. Ceark (1911). -- Observations on the Ductus Arteriosus of the Guinea Pig in Relation lo its Method of Closure. Anat. Record, 79 , p. 349 . 
Kenkedy, J. A., and S. L. Clark (1942). - Observations on the Physiological Reactions of the Ductus Arteriosus. Americ. Journ. Physiol., $136, p .140$.

Kenyon, K. W., and V. B. Scheffer (1953). - The Seals. Sea Lions and Sea Otter of the Pacific Coast. Wildlife Leciflet No. 344, U. S. Fish and Wildlife Service.

Krox, F. $\mathbb{J}$. (1838). - Catalogue of Anatomical Preparations Illustrative of the Whale. Edinburgh.

KroLL, J. A. (1959). - Over de open ducius Botalli met pulmonale hypertensie. Diss., Amsterdam.

Kulmus, J. A. (1721). - Phocae Anatome. Acia phys. med. Acad. Caes. Leop. Carol. Nat. Curios., 1, p. 9.

LABiLIARDicha (1800). - Relation du voyage à la recherche de la pérouse. Paris.

Laws, R. M. (1956). - The Elephant Seal. Falkland Islands Dependencies Survey Scientific Reports, 13, 11 .

Lindesey, A. A. (1937). - The Weddell Seal in the Bay of Whales Antarctica. Journ. Mammalogy, 18, p. 127.

LockiEY, L. M. (1954). - The Seals and the Currach. London.

Mackay. J. Y. (1886). - The Arteries of the Mead and Neck and the Rete Mirabile of the Porpoise. Proc. I'hil. Soc. Glasgow, 17, p. 366 .

Mansfield, A. W. (1958). - The Breeding Behaviour and Reproductive Cycle of the Weddell Seat. Falliand Islands Dep. Survey, Scient. Reports, 18, London.

Marscherer, L. (1901). - Beilräge znr thatomie und Physiologie des Herzens und der grossen Gefüsstämme der Wassersäugetiere. Inaug. Diss., Breslau.

Mayer, A. F. J. G. (1839). - Zur Analomie von Phoca vitulina. Analecten f. vergl. Anatomie, 2, p. 55, Bonn.

MAYER, C. (1817). - Beiträge zur Analomie des Elephanlen. Nova Acla Acad. Caes. Leop. Carol. Nat. Cur., 22 , p. 1.

Mrckef, J. F. (1831). - Syslem der vergleichenden Anatomie, Teil 5. Halle

MeLKa, J. (1926). - Beilrag zur Kenntnis der Morphologie und Obliteration des Ductus arteriosus Botalli. Anat. Anz., 61, p. 348.

Mrall, L. C.. and F. Greerwood (1879). - The Anatomy of the Indian Elephant. Journ. Anat. Phys., 13, p. 17.

Mönz-Hansex, M. (1954). - Investigations on Reproduction and Growth of the Porpoise from the Baltic. Vidensk. Medd. Dansk. Naturh. Foren., 116, p. 369 .

Mokr, E. (1952). - Die Robben der europäischen Gewässer. Monogr. d. Wildsäugetiere, 12, Frankfurt am Main. 
Morn, E. (1955). - Der Seehund. Nele Brehm Bücherei 145, Ziemsen, Wiltenberg-Lutherstadt.

Moora, J. C. (1951). - The Staus of the Manatee in the Everglades. Journ. Mammalogy, 32, p. 22.

Moore, J.G. (1957). - Newborn Young of a Caplive Manatee. Journ. Mamnalogy, 38, p. 137.

Müner (1868). - Bericht über das Wiener Tierämenei Institut für das Studienjahr 1866-1867. Oesterr. Vierteljahrschr. f. Wiss. Veterinärkande, 29, p. 28.

Murne, J. (1865). - On the Anatomy of a Fin Whale captured near Gravesend. Proc. Zool. Soc. London, p. 206.

Murx, I. (1874). - Researches upon the Anatomy of the Pinnipedia 3. Descripsive Anatomy of the Sea Lion, Otaria jubata. Trans. Zool. Soc. London, 8, p. 501.

Nolan, F. G. (1959). - Report to U.S. Fish and Wildlife Service of Scientific Data on the Grey Whale. Hollywood.

ODÉ, F. (1950). - Enkele problemen nar aanleiding van de ontwikkeling van de ductus arteriosus bij mens en rat. Ned. Tijdschr. Geneesh. Q4, p. 2139.

Opí, L. (1951). De ductus arteriosus. Diss., Leiden.

Omanney, F. D. (1985). - Do Whales descend to great Depths 3 Nature, 135, p. 430 .

Osgoon, W. H., E. A. Prable and G. H. PARKR (1911). - The Fur Seals and orher Lide of the Pribilof Islands Alaska in 1914. Bull. U.S. Bureau of Fisheries, 34, p. 1.

Osserabora, G., G. Pezzour el P. Prent (1954). - Le mécanisme physiologique de la fermeture du canal artériel. Lyon Chirargical, 19 , p. 905 .

OTraWAy, C. W. (1944). - The Anatomical Closure of the Foramen Ovale in the Equine and Bovine Heart. Veterinary Joumal, 100, pp. 111,130 .

Owex, R. (1868). - On the Anatomy of Vertebrates: 3, Mammals. London.

PArsons, J. (1743). - Some Account of the Phoca, Vifulus marinus, or Sea Calf shewed at Charing Cross in February 1742. Phil. Trans. Poy. Soc. London, 42 , p. 381 .

Pater , B. M. (1931). - The Closure of the Foramen Ovale. Am. Journ. Anal., 48, p. 19.

PEcriorz, 1. (1956). - Mikroskopisch anatomische Untersuchungen zur. Orthologie des Ductus arteriosus Botalli vom Menschen. Zeitschr. Mikp. Anat. Forschung, 62, p. 229.

Perauds, M. (1783). - Mémoires pour servir à l'histoire naturelle des animaux, I. Mém. Acad. Roy. Sci., 3. 
Ponnmanr, A. G. (1909). - The Course of the Blood through the Heart of the Fetal Mammal. Anat. Rec., 3, p. 75.

Porlumann, A. G. (1924). - The Comparative Physiology of the Circulatory Changes at Birth. Zeitschr. Morphol. Anthropol., 24, p. 191.

Pöllot, W. (1909). - Histologischer Bav und Rückbildung des Ductus arteriosus Botalli. Inaug. Diss., Heidelberg.

Portal (1683). - Dissertatio de Phoca. Regiomont.

Rafrless, T. S. (1820). - Some Account of the Dugong. Phil. Trans. Roy. Soc. London, 110, p. 174.

Rapp, W. (1837). - Die Getaceen. Stuttgart und Tübingen.

RECORD, R. G., and Th. McKEOWv (1953). - Observations relating to the Aetiology of Patent Ductus Arteriosus. British Heart Journal, 15, p. 376.

Racord, R. G., and Th. Mckewn (1955). - Anatomical Closure of the Duclus arteriosus in the Guinea Pig. Clinical Science, 14, p. 213.

Recond, R. G., and Th. Mckeown (1955a). - The Effect of Reduced Atmospheric Pressure on Closure of the Duclus arteriosus in the Guinea Pig. Clinical Science, 14, p. 225.

PeEORD, R. G., and Th. McKeown (1955b). - The Effect of Oxygen Deficiency on Closure of the Ductus arteriosus in the Newborn Guinea Pig. Clinical Science, 14, p. 711.

REynozds, S. M. R. (1956). - The Fetal and Neonatal Pulmonary Vasculature in the Guinea Pig in Relation to Hemodynamic Changes at birth. Americ. Journ. Anat., 98, p. 97.

Reyrobds, S. R. M. (1957). - Changes in the Circulation at Birth. Modern Medicine, p. 83.

Reymolds, S. R. M. G. M. Adrian and M. M. L. Prichapd (1954). Observations on Regional Circulation Times in the Lamb under Fetal and Neonatal Conditions. Contr. Embryol. Carnegie Inst., 35, p. 231.

RowLex, J. (1929). - Life History of the Sea Lions on the Californian Coast. Journ. Mammal., 10, p. 1 .

Sanctus, L. de (1879). - Monografia Zootomico-zoologica sul Capidoglio arenato a Porto S. Giorgio. Atti Accad. Lincei Cl. Sci. Phys. Ec., Ser. 3̊a, 9, p. 160.

Sanderson, I. T. (1958). - De Wereld der Dieren. Zoogdieren. Gaade, den Haag.

Schmon, R. E., and E. H. Harris (1918). - On the Time of the Postnatal Obliteration of the Fetal Blood-passages. Anat. Record, 15, p. 165.

SGHEFFER, Y. B. (1958). - Seals, Sea Lions and Walruses. Stanford Univ. Press., Stanford. 
SchilLer, H. J. (1959). - Das Herz des Löwen. Morphol. Jahrb., 100, p. 163.

Sceort, E. (1922). - Die hydrostatische Druckwirkung auf das venöse System als additioneller Faktor bei der Wirkung von Bädern. Deutsches Archiv Klin. Med.. 140, p. 359.

Sciacca, A., and M. CondoRetcr (1954). - L'involuzione dell dollo arlerioso nella cavia. Monit. Zool. Ital., 63 (suppl.), p. 282.

Shadue, A. R. (1930). - An unusual Case of Parturition in a Beaver. Journ. Mammal., 11, p. 483 .

Styertsen, E. (1941). - On the Biology of the Harp Seal. Inalradets Skrifier, 26, Oslo.

SLIJER, E. J. (1936). - Die Cetaceen, vergleichend-anatomisch und sysiematisch. Capita Zoologica, 7. Diss., Utrecht.

Suijper. E. J. (1939). - Pseudorca crassidens (Owen). Zool. Meded. Rijksmus. Nat. Hist. Leiden, 21, p. 241.

Surjper, E. J. (1956). - Some Remarks in Gestation and Birth in Cetacea and other Aquatic Mammals. Hvalrådets Skrifter, Oslo, 41.

Sujper. E. J. (1958). - Walvissen. Centen, Amsterdam. (English Translation to appear al Hutchinson's, London, 1962).

Suruper, E. J. (1958a). - Organ Weights and Symmetry Problems in Porpoises and Seals. Arch. néerl. zool., 13, suppl. 1, p. 97.

SuJper, E. J. (1960). - Die Geburt der Säugetiere. Handbnch der Zoologie (Kükenthal), Bd. 8, Lief 25, Berlin.

Sorcetry (1952). - Analogia di struttura e di mecanismo di obliteratione tre canale arterioso ed arterie ombilicali nei mammiferi. Rivista di Biologia, 44.

Stannius, H. (1841). - Ueber den Verlauf der Arterien bei Delphinus phocaena. Arch. Anat. Phys., p. 379.

Stgingmany, P. (1955). - Meine Tierkinder im Zoo. Zürich.

STgGR, W. (1927). - Variabilität und Missbildung im Schweineherzen. Anat. Anz., 63, p. 145.

Steller, G. W. (1751). - De bestiis marinis. Novi Comm. Ac. Sci. Imp. Petropolitanae, 2, p. 289.

Stephens, M. N. (1957). - The Natural History of the Oiter. U. F. A.W., London.

Stocrrr, O. (1933). - Aufzucht eines in Gefangenschaft geborenen Seehundes. Zool. Garten, N. F. 6, p. 237.

Strassman, P. (1894). - Anatomische und physiologische Untersuchumgen über den Blutkreislauf beim Neugeborenen. Arch. Gynaek., 45, p. 393. 
STRoF, G. (1923). - Untersuchungen an Rinderherzen über das Orperbleiben des Foramen ovale. Münch. Tierärzll. Wochenschr., 74, p. 293.

STRUBELT, I. (1925). - Anatomische Untersuchungen über den Verschluss des Ductus Botalli bei Kälbern und Pindern. Inaug. Diss., Tierärz l. Mochsch. Berlin.

STHUTHRs, J. (1896). - On the External Characters and some Parts of the Anatomy of a Beluga. Journ. Anat. Phys., 30, p. 124.

SWENSON, A. (1939). - Beiträge zur Renntnis von. dem histologischen Bau und dem post-embryonalen Verschluss des Ductus arteriosus Botalli. Zeitschr. Mitrr. Anat. Forsch., 46, p. 275.

Turar , W. (1868).-.-A Contribution to the Anatomy of the Pilot Whale. Journ. Anat. Phys., 2, p. 66.

Tukner, W. (1872). - An Account of the Great Finner Whale, stranded at Longniddry. Trans. R. Edinburgh, 26, p. 197.

Tunser, W. (1893). - The Lesser Rorqual in the Scottish Seas. Proc. R. Soc. Edinburgh, 19, p. 36 .

Trison, $\mathbb{E} .(1680)$. - Phocaena or the Anatomy of a Porpess, dissected at Gresham Colledge, London.

Verables, M. H., and L. S. V. Verables (1955). - Observations in a Breeding Colony of the Seal Phoca vitulina in Shetland. Proc. Zool. Soc. London, 125, p. 521.

VRotiR, W. (1822). - Specimen anatomico-zoologicum de Phocis speciatim de Phoca vitulina. Diss. Amsterdam. O. I. v. Paddenburg, Utrecht.

VRoliK, W. (1852). - Bijdrage tot de Natuur-en Onlleedkundige Kennis van den Manatus Americanus. Bijdragen $t$. d. Dierkunde, $4, \mathrm{p} .53$.

WALmSEx, R. (1938). - Some Observations on the Vascular System of a Female Fetal Finback. Publ. Carnegie Inst. Washington, 496 (Contr. to Embryol. 161), p. 107.

Wigtwas, G. (1959). - De relatie tussen coarclatio aortae en ligamentum arteriosum. Diss., Leiden.

Wuta, F. (1960). - The Northern Fur Seal. U. S. Dept. Inst. Fish and Wildlife Service, Bureau of Commercial Fisheries.

Winternte, Thomas and Legompte (1938). --. The Biology of Arteriosclerosis. 
TABLE 1

Data about the closure of the embryonic pathways in the Common Porpoise, Phocaena phocaena (L.)

\begin{tabular}{|c|c|c|c|c|c|c|c|c|c|c|}
\hline 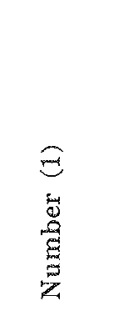 & $\stackrel{\mathscr{E}}{\stackrel{E}{n}}$ & 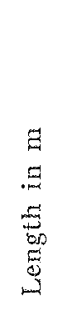 & 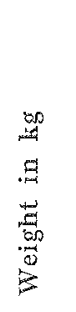 & Status of Animal & 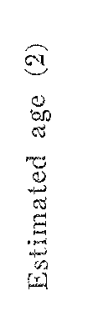 & 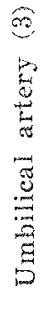 & 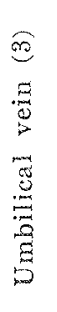 & 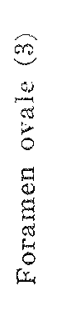 & 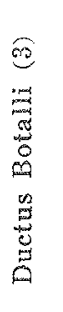 & Remarks \\
\hline Si. C & o & 67 & & Neonatus & o & o & 0 & 0 & 0 & \\
\hline Sl. F & $0^{3}$ & 68 & & Neonatus & 0 & 0 & 0 & 0 & 0 & \\
\hline 1 & $\sigma^{2}$ & 68 & 5,5 & Neonatus & 0 & 0 & $\mathrm{O}$ & o & 0 & Lungs sink; Duct, wide open \\
\hline S1. D & $\vec{\sigma}$ & 69 & & Neonatus & 0 & o & 0 & 0 & 0 & \\
\hline 2 & 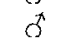 & 71 & 6 & Neonatus & 0 & 0 & 0 & o & 0 & Lungs sink \\
\hline S1. $G$ & 오 & 73 & & Neonatus & 0 & 0 & 0 & 0 & 0 & \\
\hline 4 & $q$ & 77 & 7 & Neonatus & $2 d$ & 0 & 0 & 0 & 0 & Unbil. closed. Lungs floating \\
\hline SI. $\mathrm{E}$ & q & 80 & & Neonatus & $2 d$ & 0 & 0 & 0 & $\mathrm{O}$ & Umbilicus closed \\
\hline 6 & Q & 80 & 7 & Neonatus & $5 \mathrm{~d}$ & 0 & 0 & 0 & 0 & Umbil. closed. Lungs floating \\
\hline 3 & 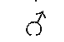 & 75 & 8 & Very young & $10 \mathrm{~d}$ & & & 0 & 0 & Umbil. more closed \\
\hline 7 & q & 86 & 10 & Suckling & $1 \mathrm{~m}$ & $\mathrm{c}$ & 0 & c & O & \\
\hline Sh. H & o+ & 93 & & Suckling & $2 \mathrm{~m}$ & $\mathrm{c}$ & 0 & $\mathrm{c}$ & $\mathrm{O}$ & Umbilicus flat \\
\hline Sh. J & q & 101 & & Suckling & $4 \mathrm{~m}$ & & & & 0 & \\
\hline L. 1 & $q$ & 105 & & Suckling & 4. $\mathrm{m}$ & & & $\mathrm{c}$ & & \\
\hline Wo. 40 & 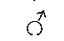 & 129 & 19 & Suckling & 4. $m$ & & 0 & $\mathrm{c}$ & c & Just closed in aorta, rest open \\
\hline G. & o & 118 & 22 & Suckling & $5 \mathrm{mo}$ & $\mathrm{c}$ & & c & $\mathrm{c}$ & Umbilicus flat. Just closed in aorta \\
\hline L. 2 & & 109 & & Suckling & $5 \mathrm{~m}$ & & & & 0 & \\
\hline Wo. 45 & 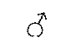 & 112 & 23 & Suckling & $5 \mathrm{~m}$ & 0 & 0 & $\mathrm{c}$ & $\mathrm{c}$ & Ductus fully closed \\
\hline Wo. 4.4 & $d$ & 125 & 23 & Suckling & $5 \mathrm{~m}$ & & & c & 0 & \\
\hline L. 3 & & 114 & & Suckling & $5 \mathrm{~m}$ & & & $\mathrm{O}-\mathrm{c}$ & 0 & In foramen 2 small openings \\
\hline \$1. $Q$ & 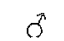 & 123 & & Suckling & $7 \mathrm{~m}$ & & & $\mathrm{c}$ & 0 & \\
\hline L. 3 & & 126 & & Suckling & $7 \mathrm{~m}$ & & & $\mathrm{c}$ & c & \\
\hline 8 & Q & 115 & 24 & Just weaned & $8 \mathrm{~m}$ & & & $\mathrm{c}$ & 0 & Teeth just broken through \\
\hline
\end{tabular}




\begin{tabular}{|c|c|c|c|c|c|c|c|c|c|c|}
\hline $11 \mathrm{D}$ & q & 123 & 35 & Just weaned & $8 \mathrm{~m}$ & $\mathrm{c}$ & 0 & $\mathrm{c}$ & 0 & Parasites \\
\hline 14 & $\sigma^{\pi}$ & $13 \hat{9}$ & 40 & Immature & $11 \mathrm{~m}$ & & & c & $\mathrm{c}$ & \\
\hline $13 \mathrm{D}$ & o & 135 & 46 & Immature & $11 \mathrm{~m}$ & c & 0 & c & 0 & \\
\hline Wo. 46 & $q$ & 155 & 46 & Neariy sex. mat. & $14 \mathrm{~m}$ & c & 0 & c & $c$ & \\
\hline $\begin{array}{l}\text { L. } 4 \\
\text { L. } 5\end{array}$ & Q & 137 & & Nearly sex. mat. & $14 \mathrm{~m}$ & & & & 0 & \\
\hline $\begin{array}{l}\text { L. } 5 \\
125\end{array}$ & $Q$ & 140 & & Nearly sex. mat. & $14 \mathrm{~m}$ & c & & c & c & \\
\hline 1. 0 & $\frac{d}{0}$ & $\begin{array}{l}134 \\
150\end{array}$ & 45 & $\begin{array}{l}\text { Just sex. mat. } \\
\text { Just sex. mat. }\end{array}$ & $\begin{array}{l}16 \mathrm{~m} \\
15 \mathrm{~m}\end{array}$ & $\mathrm{c}$ & $\mathrm{c}$ & $\begin{array}{l}\mathrm{c} \\
\mathrm{c}\end{array}$ & $\begin{array}{l}\mathrm{c} \\
\mathrm{c}\end{array}$ & Early sign of ovulation \\
\hline 17 & 要 & 143 & 42 & Sex, mat. & & & & c & $c$ & Lactating \\
\hline 15 & $\sigma$ & 142 & 45 & Sex. mat. & & & & $\mathrm{c}$ & $\mathfrak{c}$ & \\
\hline 16 & ? & 142 & 46 & Sex. mat. & & & & 0 & 0 & Pregnant \\
\hline $18 \mathrm{D}$ & $\theta$ & 145 & 48 & Sex. mat. & & & & $\mathrm{c}$ & $\mathrm{c}$ & Ductus only closed in aorta \\
\hline Wo. 41 & 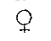 & 147 & 55 & Sex. mat. & $3 \mathrm{y}$ & & & c & $\mathrm{c}$ & \\
\hline $20 \mathrm{D}$ & $d$ & 150 & 46 & Sex. mat. & & & & c & 0 & \\
\hline $\begin{array}{l}21 \mathrm{D} \\
\text { Wo. } 42\end{array}$ & $\hat{0}$ & 152 & 57 & Sex. mat. & & & & c & $\mathrm{c}$ & \\
\hline $\begin{array}{l}\text { Wo. } 42 \\
22\end{array}$ & ? & 155 & 50 & Sex. mat. & & & & c & e & $\begin{array}{l}\text { Lactating } \\
\text { Pregnant }\end{array}$ \\
\hline $\begin{array}{l}22 \\
23\end{array}$ & 是 & $\begin{array}{l}160 \\
162\end{array}$ & $\begin{array}{l}50 \\
53\end{array}$ & $\begin{array}{l}\text { Sex. mat. } \\
\text { Sex. mat. }\end{array}$ & $6 \mathrm{y}$ & c & 0 & $\begin{array}{l}\mathrm{c} \\
\mathrm{c}\end{array}$ & $\begin{array}{l}0 \\
c\end{array}$ & \\
\hline $\begin{array}{l}23 \\
25\end{array}$ & $\delta$ & 163 & 49 & $\begin{array}{l}\text { Sex. mat. } \\
\text { Sex. mat. }\end{array}$ & $6 \mathrm{y}$ & c & $\mathrm{c}$ & $c$ & $\mathrm{c}$ & Ductus only closed in aorta \\
\hline $2-1-58$ & $e^{+}$ & 166 & 75 & Sex. mat. & & & & c & $\mathfrak{c}$ & Pregnant \\
\hline Sl. P & q & 168 & & Sex. mat. & & & & c & $\mathrm{c}$ & Pregnant \\
\hline $27 \mathrm{D}$ & ? & 170 & 67 & Sex. mat. & & & & c & $\mathrm{e}$ & \\
\hline L. 7 & & & & Sex. mat. & & & & & e & \\
\hline L. 8 & & & & Sex. mat. & & & & & c & Several specimens \\
\hline $24 \mathrm{D}$ & 9 & 162 & & old & & & & c & c & Teeth weared down; abnormal lactation \\
\hline L.4. & Q & 170 & & old & & & & & c & \\
\hline $28 \mathrm{D}$ & Q & 171 & & old & & & & c & c & \\
\hline 10 & q & 121 & 26 & Physically mature & & c & $\mathrm{c}$ & $c$ & 0 & Ail vertebr. ep. ankylosed abnormal \\
\hline L. 9 & 6 & & & Old & & & & & c & \\
\hline
\end{tabular}

(1) The numbers indicated S1. refer to Slijper (1936), most of the other numbers refer to specimens dealt with by Slijper (1958 a), The The (1837); L. $3=$ Marschner (1901); L. $4=$ Those indicated L. refer to statements in $6=$ Jackson (1845);L. 7 = Stannius (1841); L. $8=$ Cuvier (1805); L. $9=$ Cleland (1884).

(2) $\mathrm{d}=$ days $; \mathrm{m}=$ months $; \mathrm{y}=$ years.

(3) $0=$ open; $c=$ elosed 
TABLE 2

Data about the closture of the embryonic pathways in the Blne Whale, Balaenoptera musculus (L.)

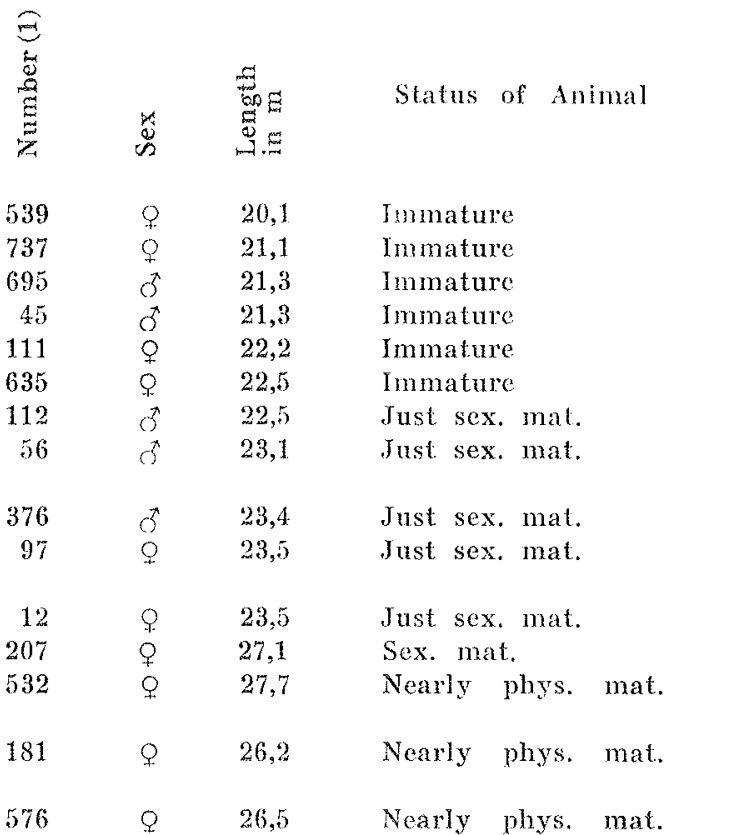

\begin{tabular}{|c|c|c|c|c|c|}
\hline & ซี่ & & Juctus Boto & alli (2) & \\
\hline 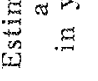 & 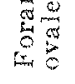 & $\begin{array}{l}\text { Length } \\
\text { in } \mathrm{cm}\end{array}$ & $\begin{array}{l}\text { Diameler: } \\
\text { in } \mathrm{cm}\end{array}$ & $\begin{array}{l}\text { Status } \\
(2)\end{array}$ & Remarks \\
\hline $31 / 2$ & $\mathrm{c}$ & & & & \\
\hline 4 & & 12 & 4,5 & $c$ & Sclerotic tissue in pulm. Completely closed \\
\hline 4 & & 11,5 & 5,2 & 0 & Sclerotic and calcified tissue in ductus \\
\hline 4 & & & 5 & 0 & Lumen $21 / 2 \mathrm{~mm}$ \\
\hline 4 & $\mathrm{c}$ & & & & \\
\hline 4. & & 13 & 5 & $\mathrm{c}$ & Middle part $(5 \mathrm{~cm})$ closed and calcified \\
\hline 5 & & & 6 & 0 & Lumen very narrow Sclerotic tissue in pulm. \\
\hline 5 & & & 7 & o & Lumen $6 \mathrm{~mm}$ \\
\hline 5 & & 13 & 5,5 & o & \\
\hline 5 & & & & c & $\begin{array}{l}\text { Wall of pulm. at entrance of ductus calcified } \\
5 \times 9 \mathrm{~cm}\end{array}$ \\
\hline 5 & & 20 & 5 & 0 & Very narrow lumen \\
\hline 11 & & 10 & 6 & 0 & \\
\hline 12 & & 20 & 6 & $c$ & $\begin{array}{l}\text { Wall of ductus and wall of pulm. caleified. Until } \\
21 / 2 \mathrm{~cm} \text { from aorta lumen open. }\end{array}$ \\
\hline 13 & & 8 & 5 & 8 & $\begin{array}{l}\text { Entrance in aorta closed rest open. Sclerotic } \\
\text { tissue in pulm. }\end{array}$ \\
\hline & & 11. & 7 & o & Slerotic tissue in pulm, and aorta, \\
\hline
\end{tabular}

(1) The numbers refer to the catches of the fioating factory "Willem Barendsz 》 in the season 1946-194\%

(2) $O=$ open ; $c=$ closed, 
TABLE 3

Data about the closure of the embryonic pathways in the Fin Whale, Balaenoptera physalus (L.)

\begin{tabular}{|c|c|c|c|c|c|c|c|c|c|}
\hline \multirow{2}{*}{ 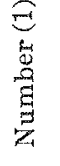 } & \multirow[b]{2}{*}{ 荡 } & \multirow{2}{*}{ 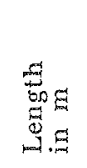 } & \multirow{2}{*}{ Status of Animal } & \multirow{2}{*}{ 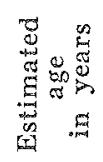 } & \multirow{2}{*}{ 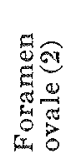 } & \multicolumn{3}{|c|}{ Dutctus Botalli (2) } & \multirow{2}{*}{ Remarks } \\
\hline & & & & & & $\begin{array}{l}\text { Length } \\
\text { in } \mathrm{cm}\end{array}$ & $\begin{array}{l}\text { Diameter } \\
\text { in } \mathrm{cm}\end{array}$ & $\underset{(2)}{\text { Status }}$ & \\
\hline 746 & $0^{\pi}$ & 20,4 & Just sex. mat. & 5 & & 12 & 7 & 0 & Lumen à $5 \mathrm{~mm}$; Calcified tissue \\
\hline 373 & $Q$ & 21,3 & Sex. mat. & 6 & $\mathrm{c}$ & & & & \\
\hline 747 & $q$ & 21,6 & Sex. mat. & 9 & & 12 & 5 & 0 & $\begin{array}{l}\text { Lumen } 6 \mathrm{~mm} \\
\text { Scler. tiss. in pulm. cale. in duct. }\end{array}$ \\
\hline 222 & $\delta$ & 19,8 & Nearly phys. mat. & 12 & c & & & 0 & \\
\hline 365 & 운 & 21,9 & Nearly phys, mat. & 13 & c & & & & \\
\hline
\end{tabular}

(1) The numbers refer to the catches of the floating factory "Willem Barendsz 》 in the season 1946-1947.

(2) $\mathrm{o}=$ open; $\mathrm{c}=$ closed. 
TABLE 4

Data about the closure of the embryonic pathways in Cetaceans not recorded in Table $1-3$

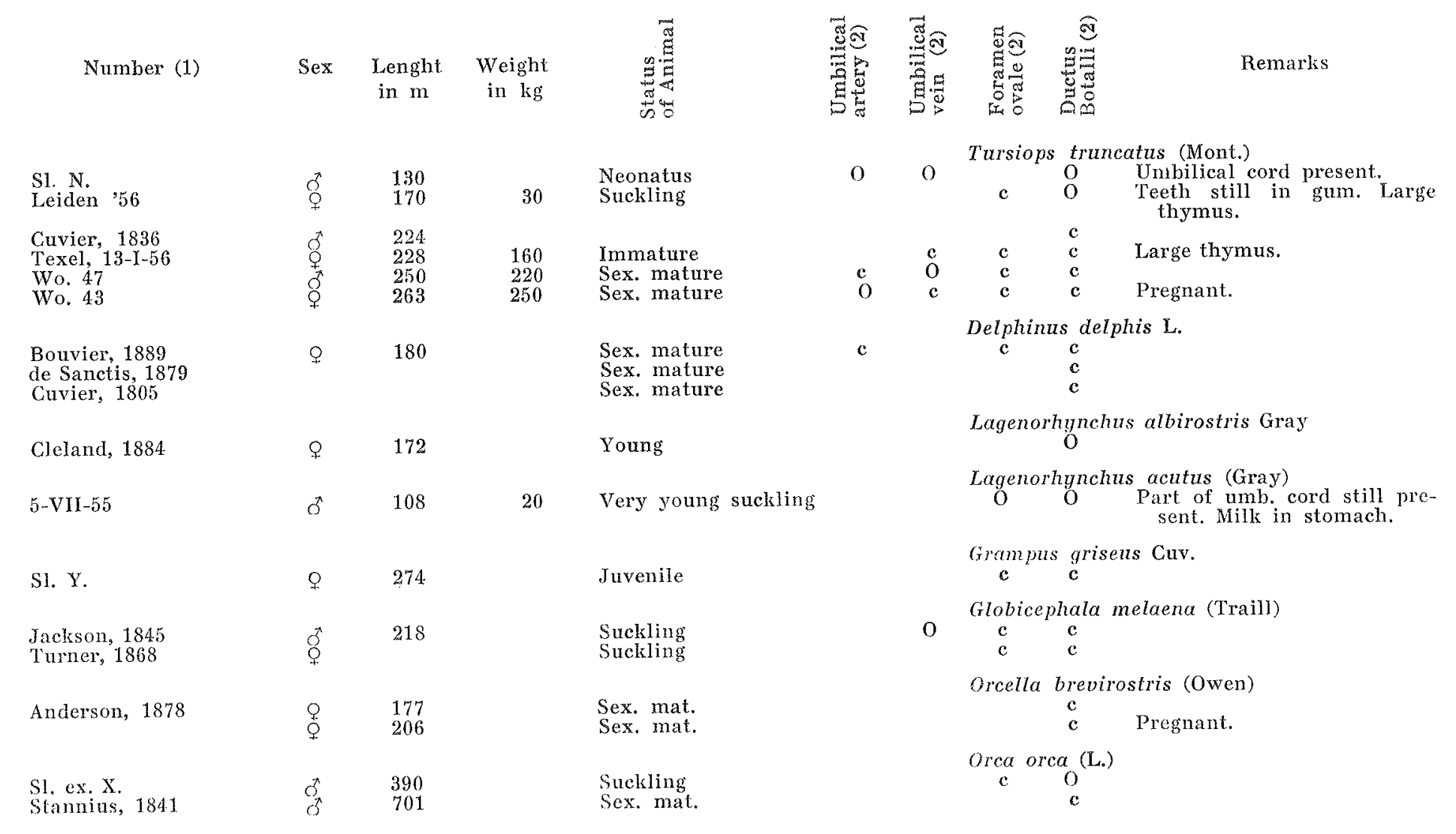




\begin{tabular}{|c|c|c|c|c|}
\hline Slijper, 1939 & 오 & 406 & & Just sex. mat. \\
\hline Burmeister, $1869 a$ & 3 & 190 & & Sex. mat. \\
\hline Struthers, 1896 & 오 & 378 & & Phys. mat. old \\
\hline $\begin{array}{l}\text { S1. ex. AA. } \\
\text { Steinshamm, } 1956 \\
\text { Bouvier, } 1892\end{array}$ & $0^{x}$ & 405 & & $\begin{array}{l}\text { Young } \\
\text { Young }\end{array}$ \\
\hline Burmeister, 1869 & $\sigma^{2}$ & 395 & & Young \\
\hline $\begin{array}{l}\text { White and Kerr, } 1917 \\
\text { Jackson, } 1895 \\
\text { de Sanctis, } 1899 \\
\text { Breskens, } 1937\end{array}$ & $\begin{array}{l}0 \\
0 \\
0 \\
0 \\
0 \\
0\end{array}$ & $\begin{array}{r}360 \\
487 \\
1500 \\
1850\end{array}$ & 60.000 & $\begin{array}{l}\text { Very young } \\
\text { Very young } \\
\text { Sex. mat. } \\
\text { Sex. mat. }\end{array}$ \\
\hline Nolan, 1959 & 웅 & 1270 & 16.000 & Sex. mat. \\
\hline $\begin{array}{l}\text { Knox, } 1838 \\
\text { Bouvier, } 1889 \\
\text { Carte Macal., } 1868 \\
\text { Turner, } 1893\end{array}$ & Q & $\begin{array}{l}302 \\
400 \\
420 \\
863\end{array}$ & & $\begin{array}{l}\text { Very young } \\
\text { Young } \\
\text { Young } \\
\text { Sex. mat. }\end{array}$ \\
\hline $\begin{array}{l}\text { Barkow, } 1862 \\
\text { Murie, } 1865 \\
\text { Knox, } 1838\end{array}$ & $\sigma^{\pi}$ & $\begin{array}{l}1371 \\
1828 \\
2347\end{array}$ & & $\begin{array}{l}\text { Immature } \\
\text { Immature } \\
\text { Sex. mat. }\end{array}$ \\
\hline $\begin{array}{l}\text { Beaureg. et Boul. } \\
\text { Turner, } 1872\end{array}$ & $\begin{array}{l}0 \\
? \\
?\end{array}$ & $\begin{array}{r}530 \\
2552\end{array}$ & & $\begin{array}{l}\text { Neonatus } \\
\text { Sex. mat. }\end{array}$ \\
\hline
\end{tabular}

Pseudorca crassidens (Owen)

Stenodelphis blainvillei Gerv.

Delphinapterus leucas (Pallas)

c Teeth completely worn down.

(I)roodon ampullatus (Forster)

c $\quad \stackrel{0}{\circ}$

Mesoplodon australis Flower.

Physeter macrocephalus L.

$\mathrm{O}$

$$
\begin{array}{ll}
\mathbf{c} & \mathrm{c} \\
\mathrm{c} & \stackrel{0}{0} \\
& 0
\end{array}
$$

Ductus wide open (finger can pass).

Eschrichtius gibbosus (Erxleb.)

0 For the first time preonant, lumen of ductus small.

Balaenoptera acutorostrata Lacép.

$$
\begin{array}{ll}
\mathrm{c} & \mathrm{O} \\
\mathrm{c} & \mathrm{O} \\
\mathrm{c} & \mathrm{c} \\
\mathrm{c} & \mathrm{c}
\end{array}
$$

Balaenoptera physalus (L.)

$\begin{array}{ll}c & 0 \\ 0 & 0\end{array}$

Balaenoptera musculus (L.)

$\begin{array}{lll}\mathrm{O} & \mathrm{O} & \\ \mathrm{c} & \mathrm{O} & \text { Pregnant. }\end{array}$

(1) Sl. = Siijper, 1936 .

(2) $0=$ open; $c=$ closed 
TABLE 5

Mata about the closure of the embryonic pathways in the Common Seal, phoca vitulina $\mathrm{L}$.

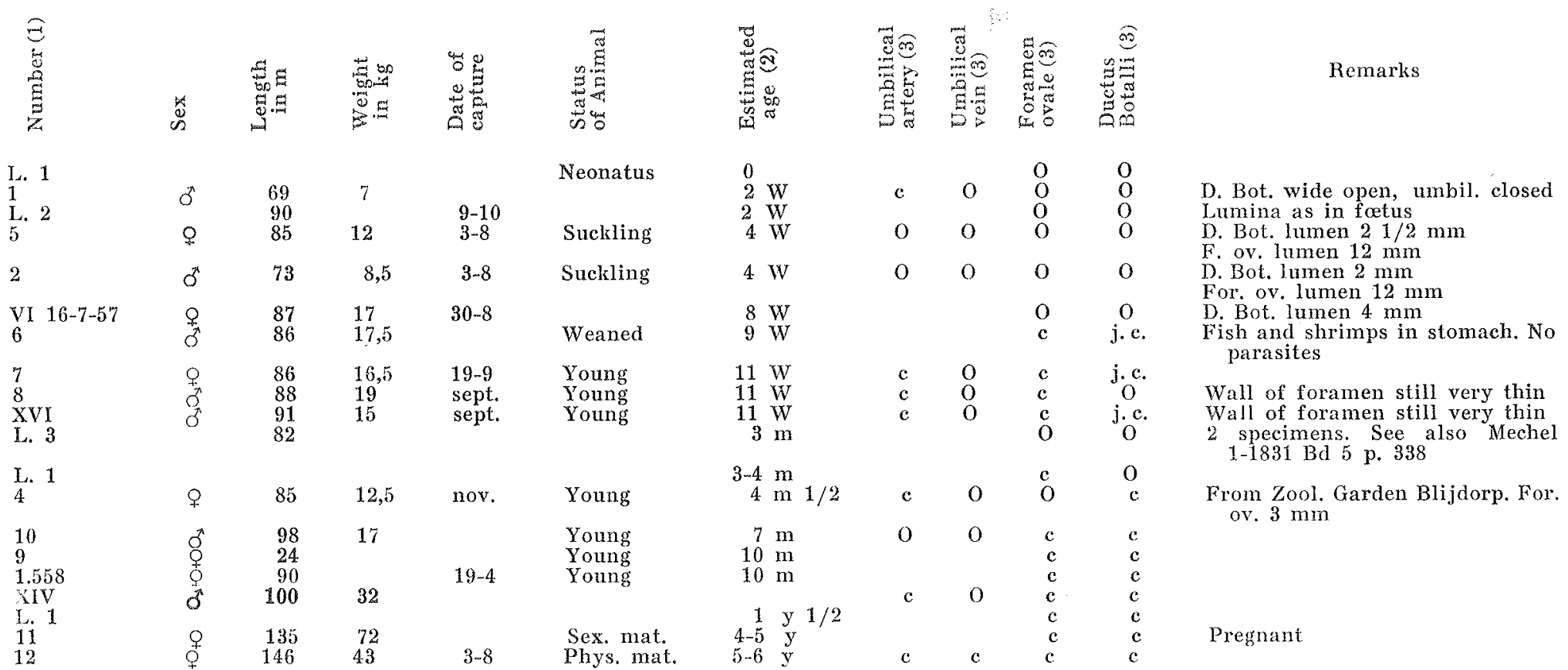

(1) Most of the numbers refer to Slijper (1958 a). Those indicated L. refer to statements in the literature, viz. : L. $1=$ Marschner (1901) L. $2=$ Garrod (1897); L. $3=$ Rapp (1837)

(3) $\mathrm{O}=$ open; $\mathrm{c}=$ closed $; \mathrm{j}$. c. $=$ just closed at aortal side. 
TABLE 6

Data about the closure of the embryonic pathways in Pinnipedia other than the Common Seal

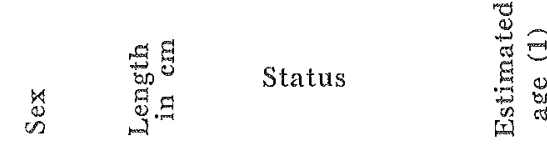

$2-9-58 \quad \mathrm{H}$

$1-9-58$ B
$31-8-58$

2-9-58 G

$1-9-58$

1532

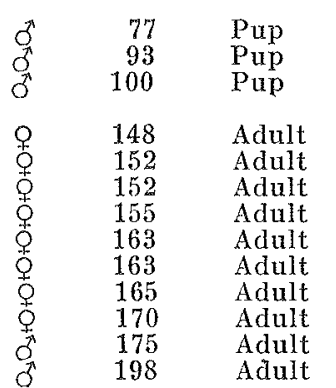

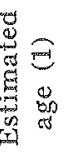

$\lim _{6-7 \mathrm{~m}}$

$6-7 \mathrm{~m}$

Q

c.

Pup

Pup

Pup

Young adult

Adult
Adult

$2-4 \mathrm{w}$

$4-6 \mathrm{w}$
$4-6 \mathrm{w}$

4. $\mathrm{y}$
Pup

要
$\mathrm{m}$
$-7 \mathrm{~m}$
$-7 \mathrm{~m}$

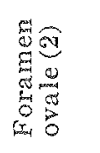

$\begin{array}{ll}\mathrm{c} & \mathrm{c} \\ \mathrm{c} & \mathrm{c} \\ \mathrm{c} & \mathrm{c} \\ \mathrm{c} & - \\ \bar{c} & \mathrm{c} \\ \mathrm{c} & \mathrm{c} \\ \mathrm{c} & \mathrm{c} \\ \mathrm{c} & \mathrm{c}\end{array}$

6 more than

$10 \mathrm{y}$

$7-14 \cdot d$

0
(1 $1 / 2-2 \mathrm{~mm}$

$\begin{array}{cc}\mathrm{c} & \mathrm{c} \\ \mathrm{O} & \mathrm{c} \\ \mathrm{mm} & \mathrm{c} \\ \mathrm{c} & \mathrm{c} \\ \mathrm{c} & \mathrm{c} \\ \mathrm{c} & \mathrm{c}\end{array}$

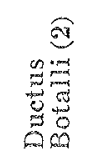

California Sea Lion, Zalophus californianus (cesson from A Kelly, La Jolla, Cal. narrow lumen in ductus damaged
completely closed

\section{damaged}

in middle of ductus still a narrow lumen damaged

\section{damaged}

damaged

Northern Fur Seal, Callorhinus ursinas (L.) from V. B. Scheffer, Seattle.

Hooded Seal, Cystophora cristata from B. Rasmussen, Bergen, Norway.
Killed $4-4-59$, Lumen in ductus already very 
1514
1539
1517
1521

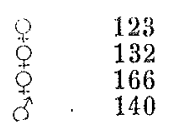

c)

c)

Subadult

WB $4: 6-47$

c

88

Young

$12 \mathrm{w}$

Steller, 1751

Hepburn, 1896

225
228

Labillardière, 1800

$4 \mathrm{~m}$

Murie, $1874 a$

240

170

Young

Owen, 1853

$$
\begin{array}{lll}
\text { Very young } & \text { Young } \\
d & 198 \quad \text { Youn }
\end{array}
$$

$10 \mathrm{y} y$

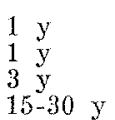

$\stackrel{c}{c}$

\section{c}

Ross Seal, Ommatophoca rossi Gray

South American Sea Lion, Otaria byronia (de Blainville), Zoo Blijdorp, Rotterdam,
Foramen very thin. Mill teeth still present Thymus present

Grey Seal, Halichoerus grypus (Fabr.) from
Prof. Hewer, London.

Monk Seal, Monachus monachus (Hermann)

Steller Sea Lion, Eumetopias jubata (Schreb.)

Walrus, Odobenus rosmarus (L.)

(1) $\mathrm{d}=$ days; $w=$ weeks ; $\mathrm{m}=$ months; $\mathrm{y}=$ years.
(2) $\mathrm{o}=$ open $; \mathrm{c}=$ closed. 